\title{
lodine intake in human nutrition: a systematic literature review
}

\author{
Ingibjörg Gunnarsdottir ${ }^{\prime}$ and Lisbeth Dahl ${ }^{2}$
}

'Unit for Nutrition Research, University of Iceland and Landspitali The National University Hospital of Iceland,

Reykjavik, Iceland; ${ }^{2}$ National Institute of Nutrition and Seafood Research (NIFES), Oslo, Norway

Abstract

The present literature review is a part of the NNR5 project with the aim of reviewing and updating the scientific basis of the 4th edition of the Nordic Nutrition Recommendations (NNR) issued in 2004. The main objective of the review is to assess the influence of different intakes of iodine at different life stages (infants, children, adolescents, adults, elderly, and during pregnancy and lactation) in order to estimate the requirement for adequate growth, development, and maintenance of health. The literature search resulted in 1,504 abstracts. Out of those, 168 papers were identified as potentially relevant. Full paper selection resulted in 40 papers that were quality assessed (A, B, or $\mathrm{C}$ ). The grade of evidence was classified as convincing, probable, suggestive, and no conclusion. We found suggestive evidence for improved maternal iodine status and thyroid function by iodine supplementation during pregnancy. Suggestive evidence was found for the relationship between improved thyroid function (used as an indicator of iodine status) during pregnancy and cognitive function in the offspring up to 18 months of age. Moderately to severely iodinedeficient children will probably benefit from iodine supplementation or improved iodine status in order to improve their cognitive function, while only one study showed improved cognitive function following iodine supplementation in children from a mildly iodine-deficient area (no conclusion). No conclusions can be drawn related to other outcomes included in our review. There are no new data supporting changes in dietary reference values for children or adults. The rationale for increasing the dietary reference values for pregnant and lactating women in the NNR5 needs to be discussed in a broader perspective, taking iodine status of pregnant women in the Nordic countries into account.

Keywords: iodine; nutritional status; nutritional requirements; nutrition policy

Received: 3 April 2012; Revised: 7 September 2012; Accepted: 18 September 2012; Published: 9 October 2012

$\mathrm{I}$ odine is an essential component of the thyroid hormones, thyroxine $\left(\mathrm{T}_{4}\right)$ and triiodothyronine $\left(\mathrm{T}_{3}\right)$, necessary for normal growth, development, and metabolism during pregnancy, infancy and throughout life (1-3). When the physiological requirements for iodine are not met, a series of functional and developmental abnormalities occur, including thyroid function abnormalities. Severe iodine deficiency results in hypothyroidism, endemic goiter and cretinism, endemic mental retardation, decreased fertility, increased prenatal death, and infant mortality (1-4). High iodine intake may also cause disturbances in the thyroid function (1-4).

In the 4th edition of the Nordic Nutrition Recommendation (NNR) (4) issued in 2004, the recommended daily intake (RDI) of iodine was kept unchanged from the 3 rd edition (1996). RDI was set to $90 \mu \mathrm{g} / \mathrm{day}$ for children aged 2-5 years, $120 \mu \mathrm{g} /$ day for children aged $6-9$ years, and $150 \mu \mathrm{g} /$ day for children from 10 years of age, adolescents, and adults. The RDI for iodine presented in NNR 2004 for children, adolescents, and adults is in line with current reference values from different countries and organizations $(1,5)$. In the 4th edition of NNR, an extra $25 \mu \mathrm{g}$ /day was recommended during pregnancy (RDI set to $175 \mu \mathrm{g} /$ day) and extra $50 \mu \mathrm{g} /$ day during lactation (RDI set to $200 \mu \mathrm{g} /$ day) to provide sufficient iodine in the breast milk (NNR 2004). These reference values were lower than the reference values of $200 \mu \mathrm{g} / \mathrm{day}$ during pregnancy and $250 \mu \mathrm{g} /$ day during lactation presented by FAO/WHO in 2005 (1). Furthermore, the WHO/UNICEF/ICCIDD recently increased reference values for pregnant women from 200 to $250 \mu \mathrm{g} /$ day (6).

The recommended indicator for measuring iodine status is based on the population median urinary iodine concentration (UIC) and iodine intake is regarded as adequate when the UIC is $100-199 \mu \mathrm{g} / \mathrm{L}(2,3)$. Population 
iodine sufficiency during pregnancy is defined by median UICs of $150-249 \mu \mathrm{g} / \mathrm{L}(6)$.

The present literature review is a part of the NNR5 project with the aim of reviewing and updating the scientific basis of the 4th edition of the NNRs (4) issued in 2004 (Nord 2004:13). A number of systematic literature reviews will form the basis for establishment of dietary reference values in the 5 th edition of NNR.

\section{Aims}

The overall aim was to review recent scientific data on health effects of iodine status (as an indicator of iodine intake). The specific objectives of the review were to assess the influence of different intakes of iodine at different life stages (infants, children, adolescents, adults, elderly, and during pregnancy and lactation), in order to estimate the requirement for adequate growth, development, and maintenance of health. In collaboration with the NNR5 horizontal group on pregnancy and lactation, we added one specific aim, that is, to assess the scientific evidence and special relevance for the Nordic setting by increasing the RDI of iodine during pregnancy and lactation from what was presented in the 4th edition of NNR.

\section{Research/key questions}

Five research questions were developed:

(1) What is the effect of insufficient iodine intake, from diet and supplements, on functional or clinical outcomes in different life stages (pregnancy, infancy, childhood, adulthood, and elderly)?

(2) What is the effect of excessive iodine intake, from diet and supplements, on functional or clinical outcomes in different life stages (pregnancy, infancy, childhood, adulthood, and elderly)?

(3) What is the association between iodine status (dose response) and clinical and functional or clinical outcomes?

(4) What is the effect of iodine intake from different sources on iodine status (UIC)?

(5) What are the effects of other nutrients, such as selenium and iron, on iodine status?

The main functional or clinical outcomes of interest were pregnancy outcome, childhood development (including cognitive function and growth), thyroid function (thyroid hormones, thyroid gland size, hyper- and hypothyroidism), metabolism, health, and weight. See Appendix 1 for search terms. Out of the five research questions, only the studies related to the first three are presented in this review, the reason being lack of data related to research questions four and five.

\section{Methods}

Search terms were defined during spring 2010, in collaboration with Sveinn Olafsson, librarian at Landspitali The National University Hospital of Iceland, Reykjavik, Iceland. The search terms are presented in Appendix 1. The final search was run in September 2010, including all the relevant population groups and clinical outcomes, resulting in 1,516 abstracts. Studies published from January 2000 until September 2010 were included. Abstract screening was conducted in October and November 2010 according to the guide for conducting Systematic Literature Reviews for the 5th edition of the NNRs. Inclusion criteria in the abstract screening process were the following: relevant to iodine nutrition in the Nordic countries, Nordic or English language, $\geq 50$ subjects, representative samples of the population or specific sub-samples of the population, preferably using UIC (spot samples or 24-h collections) as indicator of iodine status. Other potential indicators of iodine status and thyroid function, such as thyroid volume (TV), thyroid-stimulating hormone (TSH), T3 and T4, were also included. Most cross-sectional studies, only describing iodine status without clinical outcomes of interest for this review, were excluded at this point. Exceptions were studies conducted in one of the Nordic countries or studies with clinical outcomes of interest that might not be covered by data from cohort studies or intervention trials.

The overall aim of the present work was to review and update the scientific basis of the NNRs (NNR 4th edition), issued in 2004 (Nord 2004:13). As a systematic review was not used as basis for the NNR 2004, we decided to order some review papers along with original papers. The reason for this decision was also related to the special aim of the current review to assess the scientific basis for recently increased reference values from WHO/UNICEF/ICCIDD for pregnant women (6), and the relevance for the Nordic setting. All together 276 full papers were ordered, of which 108 papers were immediately excluded and not included in the full paper selection (86 overviews, 19 editorials, commentary, prize lectures, opinions or letters to the editors, and 3 publications that had been withdrawn), leaving 168 publications. Full paper screening was conducted in February 2011, where 128 papers were excluded, leaving 40 papers selected for quality assessment. Reasons for exclusion are provided in Appendix 2. The selected papers were grouped according to clinical outcomes and different age stages into the following categories: pregnancy and lactation, including endpoints such as birth outcome, development, and health of the offspring $(n=16)$; children, including endpoints such as cognitive function and development $(n=9)$; excessive iodine intake $(n=4)$; and adults $(n=2)$. Studies from the Nordic countries $(n=13)$ were assessed separately in order to get an 
overview of iodine nutrition in the Nordic countries. Many of the Nordic studies only included descriptive information, while others were included in the relevant categories (according to clinical endpoints presented in each paper) at a later stage $(n=4$, all in the pregnancy and lactation category).

To evaluate the quality of the selected articles $(n=40)$, we used the Quality Assessment Tool (QAT) received from the NNR5 secretary. The QAT included questions about study design, recruitment, compliance, dietary assessment, confounders, statistics, outcomes, and so on. The summary of findings from studies graded as A or B according to QAT are presented in summary Tables 1-6. Detailed information is provided in evidence tables (Appendix 3-7). Main results of the papers graded $\mathrm{C}$ are given in the text, but those studies are not used in the final grading of evidence. The grade of evidence was classified as convincing, probable, suggestive, and no conclusion, in line with criteria introduced in the Systematic literature review (SLR) guide for the 5th edition of NNR.

\section{Results}

\section{Pregnancy and lactation}

lodine status and thyroid function

Studies relating iodine status during pregnancy to maternal and/or neonatal thyroid function are presented in Table 1 (details are provided in Appendix 3). An Italian trial (7) assessed iodine status and thyroid function in women after supplementation of $200 \mu \mathrm{g}$ iodine or $50 \mu \mathrm{g}$ iodine per day during pregnancy and up to 6 months after delivery. Improved iodine status was observed in both groups, but no difference in thyroid function was found between groups. The most relevant studies in the Nordic perspective are those from Denmark $(8,9)$. The study by Nøhr and Laurberg (9) included healthy pregnant women with no previous history of thyroid disease, comparing maternal and neonatal thyroid function between mothers receiving $150 \mu \mathrm{g}$ iodine as a supplement during pregnancy to those not receiving any supplements. Although small difference in thyroid function was seen between groups, the study suggests that iodine supplementation of the mother will, in general, not improve fetal thyroid function in areas such as Denmark with mild iodine deficiency. A randomized controlled trial was conducted by the same research group among women with thyroid peroxidase antibodies (TPO-Ab), showing that it is unlikely that supplementation of $150 \mu \mathrm{g} /$ day will have adverse effects in TPO-Ab women living in an area with mild-to-moderate ID (8).

Iodine nutrition of pregnant women from Norway $(n=119)$ was studied by Brantsæter (C-study) and colleagues (10). Women using dietary supplements had median iodine intake of $215 \mu \mathrm{g} /$ day (range 106526) compared with $122 \mu \mathrm{g} /$ day (range 25-340) among non-supplement users. The median UIC was also significantly higher in iodine supplement users $(190 \mu \mathrm{g} / 24 \mathrm{~h}$ for FFQ and 220 for FD) than in non-supplement users $(110 \mu \mathrm{g} / 24 \mathrm{~h})(10)$.

Pregnancy complications and pregnancy outcomes

All studies in this category were evaluated as low-quality studies (C) due to high drop-out rate, or other methodological issues (data not shown). Higher birth weight of infants whose mothers had UIC 50-99 $\mu \mathrm{g} / \mathrm{L}$ compared with those with UIC $<50 \mu \mathrm{g} / \mathrm{L}$ was reported in a cohort study from Spain (11). Three more studies assessed the association between iodine status and reproductive failure (12) or pregnancy complications (13-14).

\section{Cognitive function}

Table 2 (details are provided in Appendix 4) describes studies relating prenatal indicators of iodine status to cognitive function in the offspring. In the study by Choudhury and Gorman (15), Chinese infants were stratified into iodine deficiency groups (ID) by cord blood TSH concentration. Lower mental developmental index (MDI) was observed in the group with highest cord blood TSH. The third study in Table 2 describes results from Project Viva (16) where associations between maternal as well as newborn thyroid function and cognitive function were assessed. Higher level of $T_{4}$ in newborns was associated with slightly lower scores on the visual recognition memory test at 6 months. However, no association was observed between maternal or newborn thyroid function and cognitive function at 3 years. It should be noted that low number of women had abnormal thyroid function in the study. Other studies in this category were quality graded as C-studies, as the statistical analysis was questioned or potential confounding factors not adjusted for (data not shown). The Berbel study (17) was a non-randomized intervention study where iodine supplementation (200 $\mu \mathrm{g} \mathrm{KI} /$ day) was initiated at 4-6 weeks or 12-14 weeks of pregnancy or after delivery. The study suggests that delay in maternal iodine supplementation increases the risk of neurocognitive developmental delay of their offspring. Only $11-12 \%$ of the total study population was included in the analysis as the authors established extensive exclusion criteria in order to obtain comparably homogenous groups of children. In a non-randomized intervention study by Velasco and colleagues from 2009, pregnant women were provided with $300 \mu \mathrm{g}$ iodine in the intervention group, while a control group received no supplementation. Psychomotor development index (PDI, which is one of three scales of the Bayley Scales of Infant Development used in the study) was significantly higher in children of mothers in the intervention group than the control group (18). However, lactation was found to be a confounding factor explaining the variance in the PDI. Other possible 
Table 1. Summary table. Iodine status and iodine supplementation in pregnancy; pregnancy outcome and thyroid function in the mother and offspring

\begin{tabular}{|c|c|c|c|c|c|c|c|}
\hline $\begin{array}{l}\text { Author, year, } \\
\text { (reference number.) }\end{array}$ & Population & $\begin{array}{c}\text { No. of } \\
\text { participants }\end{array}$ & $\begin{array}{l}\text { Intervention/ } \\
\text { exposure }\end{array}$ & $\begin{array}{l}\text { Outcome } \\
\text { variable }\end{array}$ & Effect & $\begin{array}{l}\text { Study } \\
\text { quality }\end{array}$ & Comments \\
\hline $\begin{array}{l}\text { Antonangeli } \\
\text { et al. } 2002 \text { (7) }\end{array}$ & Pregnant women & $n=67$ & $\begin{array}{l}\text { Supplementation of } 200 \mu \mathrm{g} / \\
\text { day vs. } 50 \mu \mathrm{g} \text { iodine }\end{array}$ & $\mathrm{UIC/TV}$ & $\begin{array}{l}\text { Six months after delivery UIC was } \\
230 \mu g / g \text { creatinine in group A and } \\
128 \mu g / g \text { creatinine in group B. NS } \\
\text { difference in TV. }\end{array}$ & B & $\begin{array}{l}\text { Observed difference in UIC after } \\
\text { randomization, but no statistical } \\
\text { test reported on if this difference } \\
\text { is statistically significant. }\end{array}$ \\
\hline $\begin{array}{l}\text { Nøhr \& Laurberg, } \\
2000 \text { (9) }\end{array}$ & $\begin{array}{l}\text { Pregnant women/ } \\
\text { Infants }\end{array}$ & $n=144$ & $\begin{array}{l}\text { I } 50 \mu g \text { iodine supplement } \\
(+I) \text { or no iodine (no I). }\end{array}$ & TSH & $\begin{array}{l}\text { Mothers in the }+ \text { I group had lower } \\
\text { TSH (mU/L), than the no I group. The } \\
+ \text { I group of neonates had higher } \\
\text { TSH than the no I group. }\end{array}$ & B & $\begin{array}{l}\text { The study suggests that iodine } \\
\text { supplementation of the mother } \\
\text { will, in general, not improve fetal } \\
\text { thyroid function in areas such as } \\
\text { Denmark with mild iodine defi- } \\
\text { ciency. A slightly inhibitory effect } \\
\text { may be expected, which is prob- } \\
\text { ably not of clinical significance. }\end{array}$ \\
\hline $\begin{array}{l}\text { Nøhr et al., } \\
2000 \text { (8) }\end{array}$ & $\begin{array}{l}\text { Pregnant women with } \\
\text { thyroid peroxidase } \\
\text { antibodies (TPO-Ab) }\end{array}$ & $n=66$ & $\begin{array}{l}\text { I50 } \mu \mathrm{g} \text { iodine supplement or } \\
\text { no iodine supplementation. }\end{array}$ & $\begin{array}{l}\text { Postpartum thyroid } \\
\text { dysfunction (PPTD) }\end{array}$ & $\begin{array}{l}\text { TPO-AB level at screening was a } \\
\text { good predictor of the PPTD risk. No } \\
\text { statistical significant difference in the } \\
\text { frequency of PPTD in the three } \\
\text { groups, with no significant increase in } \\
\text { the prevalence, severity, or duration } \\
\text { of PPTD when } 150 \mathrm{mg} \text { iodine was } \\
\text { given to TPO. }\end{array}$ & A & $\begin{array}{l}\text { Unlikely that supplementation of } \\
150 \mu g / \text { day will have adverse } \\
\text { effects in TPO-Ab women living } \\
\text { in an area with mild to moderate } \\
\text { ID. }\end{array}$ \\
\hline
\end{tabular}

SGA = short for gestational age, TV = thyroid volume, $\mathrm{TSH}=$ thyroid-stimulating hormone. 


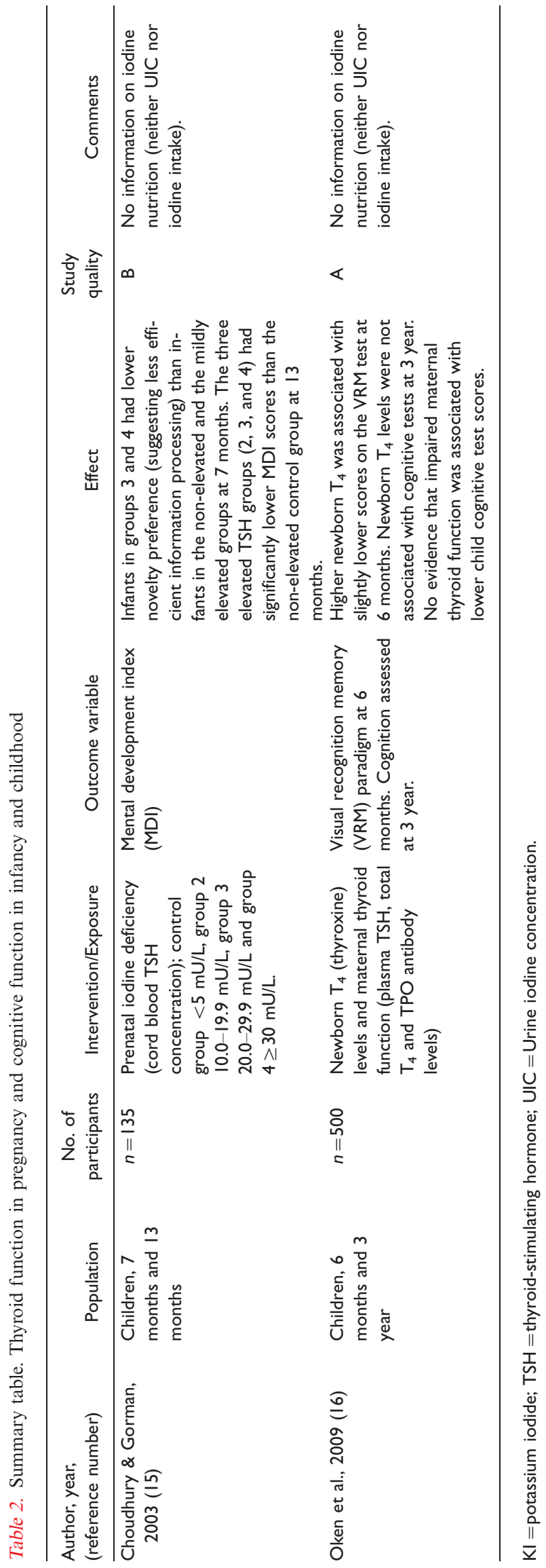

confounding variables were not controlled for and the results should therefore be considered as preliminary. In a study from China, cognitive function was assessed in children (5- go 7-year-old follow up) whose mothers initiated iodine supplementation during different stages of pregnancy (early: 1st, 2nd or late: 3rd trimester) and in a control group of children receiving iodine supplementation from 2 years of age (19). The main results point towards the suggestion that children would benefit from their mothers iodine supplementation during pregnancy in the particular population studied.

\section{Lactation}

The literature search did not result in many papers related to lactation, and only three papers in this area were selected for quality assessment. A Danish study from 2004 (B study according to quality assessment), that was already included in the NNR 4th edition $(4,20)$, showed that the level of iodine in the breast milk of smokers was $26.0 \mu \mathrm{g} / \mathrm{L}(23.2-29.1 \mu \mathrm{g} / \mathrm{L})$ and in nonsmokers $53.8 \mu \mathrm{g} / \mathrm{L}(49.4-58.5 \mu \mathrm{g} / \mathrm{L}), p<0.001$. Significant differences were also found in the infants, as the urinary iodine in infants with smoking mothers was $33.3 \mu \mathrm{g} / \mathrm{L}$ (29.9-37.2) versus $50.4 \mu \mathrm{g} / \mathrm{L}(46.0-55.1 \mu \mathrm{g} / \mathrm{L})$ in nonsmokers. Although the main message to breastfeeding mothers would be not to smoke, this study highlights the importance of obtaining enough iodine from the diet or through supplementation.

Several methodological issues (such as low participation rate and lack of adjustments for potential confounders) where observed during quality assessment of the other two studies in this category (21-22). UIC was higher in formula-fed infants than breastfed in a study from New Zealand, although no information was provided on the iodine status of the lactating mothers (21). In an Australian study, a correlation between iodine status of the mothers and iodine content of breast milk was found (22).

\section{Children}

Cognitive function

Results of three studies are presented in Table 3 (details are provided in Appendix 5) (23-25), all suggesting improved cognitive function in 6- to 13-year-old children related to iodine supplementation or improved iodine status. The results from the Gordon study, performed in New Zealand, might be relevant in the Nordic setting since the study includes children from a mildly iodinedeficient area (UIC $63 \mu \mathrm{g} / \mathrm{L}$ at baseline). The study suggests that mildly iodine-deficient children might benefit from iodine supplementation of $150 \mu \mathrm{g} / \mathrm{day}$, in order to attain their full intellectual potential. However, the two other studies might not be relevant in the Nordic perspective, including children from iodine-deficient area of Albania and North Benin. A cross-sectional study from Spain points in the same direction (26), where an 
Table 3. Summary table. Iodine supplementation or improved iodine status in childhood and cognitive function

\begin{tabular}{|c|c|c|c|c|c|c|c|}
\hline $\begin{array}{l}\text { Author, year, } \\
\text { (reference number) }\end{array}$ & Population & No. of participants & Intervention/exposure & Outcome variable & Effect & Study quality & Comments \\
\hline $\begin{array}{l}\text { Gordon et al., } \\
2009 \text { (23) }\end{array}$ & $\begin{array}{l}\text { Children, } \\
10-13 \text { years }\end{array}$ & $\begin{array}{l}\text { I group } n=84 \text { and placebo } \\
n=82 .\end{array}$ & I $50 \mu \mathrm{g}$ I tablet vs. placebo & $\begin{array}{l}\text { Cognitive } \\
\text { performance }\end{array}$ & $\begin{array}{l}\text { Cognitive performance } \\
\text { improved in the I group } \\
\text { ( } 2 \text { out of } 4 \text { subtests) }\end{array}$ & B & $\begin{array}{l}\text { Relevant in a Nordic } \\
\text { perspective since the study is } \\
\text { among children in mildly } \\
\text { iodine-deficient area. }\end{array}$ \\
\hline $\begin{array}{l}\text { Zimmermann } \\
\text { et al., } 2006 \text { (24) }\end{array}$ & $\begin{array}{l}\text { Children } \\
10-12 \text { years }\end{array}$ & $\begin{array}{l}\text { I group } n=159 \text { and placebo } \\
n=|5|\end{array}$ & $\begin{array}{l}400 \mathrm{mg} \text { iodine as oral } \\
\text { iodized oil vs. placebo. }\end{array}$ & $\begin{array}{l}\text { Cognitive and } \\
\text { motor } \\
\text { performance }\end{array}$ & $\begin{array}{l}\text { Cognitive and motor performance } \\
\text { improved in the I group ( } 4 \text { out of } \\
7 \text { subtests) }\end{array}$ & B & $\begin{array}{l}\text { Study from an iodine-deficient } \\
\text { area in Albania. Might not be } \\
\text { relevant for the Nordic } \\
\text { countries. }\end{array}$ \\
\hline $\begin{array}{l}\text { Van den Briel } \\
\text { et al., } 2000 \text { (25) }\end{array}$ & $\begin{array}{l}\text { Children } \\
6-12 \text { years }\end{array}$ & $\begin{array}{l}\text { Improved group } \\
(n=128), \text { unchanged group } \\
(n=68) .\end{array}$ & $\begin{array}{l}\text { lodine status changed from severe } \\
\text { iodine deficiency to moderate, } \\
\text { from severe to normal-mild, or } \\
\text { from moderate to normal-mild. }\end{array}$ & $\begin{array}{l}\text { Mental and } \\
\text { psychomotor } \\
\text { performance }\end{array}$ & $\begin{array}{l}\text { Greater increase in } \\
\text { performance on the combination } \\
\text { associated with improved iodine } \\
\text { status }\end{array}$ & B & $\begin{array}{l}\text { Study includes schoolchildren } \\
\text { in Benin and reflects not } \\
\text { Nordic countries }\end{array}$ \\
\hline
\end{tabular}

$\mathrm{I}=$ iodine.

Table 4. Summary table. Iodine status and health outcomes in adults and elderly

\begin{tabular}{|c|c|c|c|c|c|c|c|}
\hline $\begin{array}{l}\text { Author, year, } \\
\text { (reference } \\
\text { number) }\end{array}$ & Population & No. of participants & Intervention/Exposure & $\begin{array}{l}\text { Outcome } \\
\text { variable }\end{array}$ & Effect & $\begin{array}{l}\text { Study } \\
\text { quality }\end{array}$ & Comments \\
\hline $\begin{array}{c}\text { Ayturk et al., } \\
2009 \text { (32) }\end{array}$ & $\begin{array}{l}\text { Newly diagnosed patients } \\
\text { with metabolic syndrome } \\
\text { (18-74 years) and controls } \\
\text { living in a mild-to moderate } \\
\text { iodine deficiency area }\end{array}$ & $\begin{array}{l}n=539 ; n=278 \text { in the } \\
\text { metabolic syndrome group } \\
\text { ( } 33.1 \% \text { male) and } n=261 \\
\text { in the control group } \\
(30.7 \% \text { male) }\end{array}$ & & $\begin{array}{l}\text { Thyroid } \\
\text { volume }\end{array}$ & $\begin{array}{l}\text { TSH was significantly correlated with } \\
\text { the presence of metabolic syndrome. } \\
\text { Insulin resistance, waist circumference and } \\
\text { triglycerides independent predictors of } \\
\text { thyroid volume. }\end{array}$ & B & $\begin{array}{l}\text { No information on iodine } \\
\text { nutrition (neither urine } \\
\text { iodine nor iodine intake). }\end{array}$ \\
\hline $\begin{array}{l}\text { Hoption } \\
\text { Cann et al., } \\
2007 \text { (33) }\end{array}$ & Males $25-74$ years & $n=4,234$ ( $n=197$ cases $)$ & $\begin{array}{l}\text { Tertiles of iodine/creatinine cate- } \\
\text { gories }(<20 \mathrm{I} \mu \mathrm{g} / \mathrm{g} n=\mathrm{I}, 452,20 \mathrm{I}- \\
345 \mu \mathrm{g} / \mathrm{g} n=\mathrm{I}, 554,>345 \mu \mathrm{g} / \mathrm{g} n= \\
\mathrm{I}, 228, \text { referred to as low, moder- } \\
\text { ate and high levels }\end{array}$ & $\begin{array}{l}\text { Prostate } \\
\text { cancer } \\
\text { incidence }\end{array}$ & $\begin{array}{l}\text { Risks of prostate cancer between tertiles } \\
\text { of lodine/creatinine categories NS after } \\
\text { adjustments for potential confounding } \\
\text { factors. History of thyroid disease was } \\
\text { associated with greater than twofold } \\
\text { increased risk. }\end{array}$ & B & $\begin{array}{l}\text { The role of iodine remains } \\
\text { speculative. A role of } \\
\text { thyroid disease and/or } \\
\text { factors contributing to } \\
\text { thyroid disease as a risk } \\
\text { factor for prostate } \\
\text { carcinogenesis warrants } \\
\text { additional investigation. }\end{array}$ \\
\hline
\end{tabular}


Table 5. Summary table. Excessive intake of iodine

\begin{tabular}{|c|c|c|c|c|c|c|c|}
\hline $\begin{array}{l}\text { Author, year, } \\
\text { (reference number) }\end{array}$ & Population & $\begin{array}{c}\text { No. of } \\
\text { participants }\end{array}$ & $\begin{array}{l}\text { Intervention/ } \\
\text { exposure }\end{array}$ & Outcome variable & Effect & $\begin{array}{l}\text { Study } \\
\text { quality }\end{array}$ & Comments \\
\hline $\begin{array}{l}\text { Zimmermann } \\
\text { et al., } 2005 \text { (34) }\end{array}$ & $\begin{array}{l}\text { Children } \\
6-12 \text { years }\end{array}$ & $n=3,319$ & $\begin{array}{l}\text { UIC }<300 \mu \mathrm{g} / \mathrm{L}, \\
\text { UIC } 300-500 \mu \mathrm{g} / \mathrm{L}, \\
\text { UIC }>500 \mu \mathrm{g} / \mathrm{L}\end{array}$ & $\begin{array}{l}\text { Thyroid volume } \\
\text { (TV) }\end{array}$ & $\begin{array}{l}\text { UIC of } 300-500 \mu \mathrm{g} / \\
\mathrm{L} \text { not associated } \\
\text { with increased TV. } \\
\text { TV started to } \\
\text { increase at a UIC } \\
\approx 500 \mu \mathrm{g} / \mathrm{L} \text {. }\end{array}$ & B & $\begin{array}{l}\text { The authors don't } \\
\text { rule out adverse } \\
\text { effects of UIC } \\
\text { in the range of } \\
300-500 \mu \mathrm{g} / \text { day } \\
\text { not detected } \\
\text { in this study }\end{array}$ \\
\hline
\end{tabular}

$\mathrm{UIC}=$ urinary iodine concentration.

intelligence quotient below the 25th percentile was significantly related to UI below $100 \mu \mathrm{g} / \mathrm{L}$ (OR 1.4, $p=0.02$ ), adjusted for potential confounding factors (data neither shown in Table 3 nor included in grading of evidence).

\section{Other outcomes}

Only cross-sectional studies were retrieved studying the relationship between iodine status or iodine supplementation and outcomes such as hearing (27), body composition $(28,29)$, growth, and insulin-like-growth factor-I (30). References to these studies are only included in this review for informational purpose as cohort studies or intervention studies were lacking (data not shown). In an intervention study by Zimmerman (graded as B study) iodine-deficient children (UI at baseline $46 \mu \mathrm{g} / \mathrm{L}$ ) were supplemented with iodized oil or iodized salt for 5-6 months. A significant increase was observed in UI in the iodine group (UI $158 \mu \mathrm{g} / \mathrm{L}$ at endpoint), while total and LDL-cholesterol concentration as well as C-peptide decreased (data not shown) (31).

\section{Adults and elderly}

The literature search did not result in many studies, including adults and elderly in relation to iodine. Only two publications were selected for quality assessment in this category, both graded as B studies (Table 4, details are provided in Appendix 6). Subjects with the metabolic syndrome were found to have increased TV and nodule prevalence, and insulin resistance was suggested as an independent risk factor for nodule formation in an iodine-deficient environment (32). However, no information was provided on iodine nutrition (neither urine iodine nor iodine intake), making the study less relevant for the purpose of NNR. Prostate cancer incidence according to UIC concentration (7- to 21-year followup) was assessed in the First National Health and Nutrition Examination Survey Epidemiological Followup Study (NHEFS) (33). After adjustments for potential confounding factors, the association found turned out to be non-significant. However, reported history of thyroid disease was associated with greater than two-fold increased risk of prostate cancer.

\section{Excessive intake}

Four studies related to excessive iodine intake were a subject to quality assessment by the group. In children, $\mathrm{UIC} \geq 500 \mu \mathrm{g} / \mathrm{L}$ was found to be associated with increasing Tvol in 6- to 12-year-old children, while UIC 300-500 $\mu \mathrm{g} / \mathrm{L}$ was not (34) (Table 5, details are provided in Appendix 7). Results of other selected papers in this category should be interpreted with caution due to lack of information, especially related to adjustments for potential confounding factors (35-37) (data not shown). A prospective community-based survey among 13-year-old Chinese children, examined again 5 years later, found no difference in occurrence of autoimmune hyperthyroidism between communities with median UIC of 88,214 , and $634 \mu \mathrm{g} / \mathrm{L}$ (35). A case-control study (36) showing small but significant difference in UIC between women with autoimmune subclinical hypothyroidism and the matched controls $(327 \pm 113$ vs. $274 \pm 99 \mu \mathrm{g} / \mathrm{L}, p<0.01)$, and a Chinese cohort study by Guan et al. (37) suggested that postpartum thyroiditis (PPT) in pregnant women is triggered by high (defined as UIC $>300 \mu \mathrm{g} / \mathrm{L}$ ) iodine intake.

\section{lodine nutrition in the Nordic countries}

The majority of the studies in the area of iodine nutrition from the Nordic countries are from Denmark. In total, 13 studies from Nordic countries were selected for quality assessment. Results of four of them have already been presented in the section on pregnancy and lactation $(8-10,20)$. Main results of the studies from the Nordic countries are presented in Tables 6 and 7 .

The effect of iodization of salt on iodine status in Denmark The Danish Investigation of Iodine Intake and Thyroid Disease (DanThyr) is the official clinical monitoring of 
Table 6. Summary table. Mandatory salt iodization in Denmark

\begin{tabular}{|c|c|c|c|c|c|c|c|}
\hline $\begin{array}{l}\text { Author, year, } \\
\text { (reference number) }\end{array}$ & Population & No. of participants & $\begin{array}{l}\text { Intervention/ } \\
\text { exposure }\end{array}$ & Outcome variable & Effect & Study quality & Comments \\
\hline $\begin{array}{l}\text { Pedersen et al., } \\
2002 \text { (38) }\end{array}$ & $\begin{array}{l}\text { Adults } \\
18-65 \text { years }\end{array}$ & $\begin{array}{l}n=310,124 \text { in the Aalborg } \\
\text { area and } n=225,707 \text { in } \\
\text { the Copenhagen area }\end{array}$ & $\begin{array}{l}\text { Mandatory salt } \\
\text { iodization } \\
(13 \mu \mathrm{g} / \mathrm{g})\end{array}$ & $\begin{array}{l}\text { Incidence rates of } \\
\text { hyper- and hypothyroidism }\end{array}$ & $\begin{array}{l}\text { lodine supplementation may increase } \\
\text { the incidence of overt hypothyroidism } \\
\text { even if the population is moderately } \\
\text { iodine deficient. }\end{array}$ & B & $\begin{array}{l}\text { The optimal level of iodine } \\
\text { intake to prevent thyroid } \\
\text { disease may be a relatively } \\
\text { narrow range around } 150 \mu \mathrm{g} / \text { day. }\end{array}$ \\
\hline $\begin{array}{l}\text { Rasmussen et al., } \\
2009 \text { (39) }\end{array}$ & $\begin{array}{l}\text { Adults } \\
18-65 \text { years }\end{array}$ & $n=4,649$ and $n=3,570$ & $\begin{array}{l}\text { Mandatory salt } \\
\text { iodization } \\
(13 \mu \mathrm{g} / \mathrm{g})\end{array}$ & $\mathrm{UIC}$ and FFQ & $\begin{array}{l}\text { lodine excretion }(\mu \mathrm{g} / \mathrm{L} \text { and } \\
\mu \mathrm{g} / 24 \mathrm{~h}) \text { increased significantly in all } \\
\text { age and sex groups. }\end{array}$ & B & $\begin{array}{l}\text { lodine intake is at recommended } \\
\text { level, however in the youngest } \\
\text { age groups in both cities and in } \\
\text { women aged } \\
40-45 \text { year living } \\
\text { in Aalborg, the iodine intake is } \\
\text { below the recommendation. } \\
\text { No groups with excessive } \\
\text { iodine intake were identified. }\end{array}$ \\
\hline $\begin{array}{l}\text { Vejbjerg et al., } \\
2007 \text { (40) }\end{array}$ & $\begin{array}{l}\text { Adults } \\
1865 \text { years }\end{array}$ & $n=4,649$ and $n=3,570$ & $\begin{array}{l}\text { Mandatory salt } \\
\text { iodization } \\
(13 \mu g / g)\end{array}$ & Thyroid volume & $\begin{array}{l}\text { Lower thyroid volume in all } \\
\text { age groups. }\end{array}$ & B & $\begin{array}{l}\text { The decline in thyroid volume } \\
\text { was largest in the regions with } \\
\text { former moderate iodine } \\
\text { deficiency. }\end{array}$ \\
\hline $\begin{array}{l}\text { Vejbjerg et al., } \\
2008 \text { (45) }\end{array}$ & $\begin{array}{l}\text { Adults } \\
1865 \text { years }\end{array}$ & $n=4,649$ and $n=3,570$ & $\begin{array}{l}\text { Mandatory salt } \\
\text { iodization } \\
(13 \mu g / g)\end{array}$ & $\begin{array}{l}\text { Thyroid volume and } \\
\text { TSH in relation to } \\
\text { smoking. }\end{array}$ & $\begin{array}{l}\text { Smokers have lager thyroid volume } \\
\text { than non-smokers; however, the } \\
\text { difference in thyroid volume was } \\
\text { reduced after iodization. The effect of } \\
\text { smoking on TSH and free } \mathrm{T}_{4} \text { was } \\
\text { unchanged after iodization. }\end{array}$ & B & $\begin{array}{l}\text { The effect of smoking on } \\
\text { thyroid volume seems to be } \\
\text { dependent on iodine intake. }\end{array}$ \\
\hline $\begin{array}{l}\text { Vejbjerg et al., } \\
2009 \text { (4I) }\end{array}$ & $\begin{array}{l}\text { Adults } \\
18-65 \text { year }\end{array}$ & $n=4,649$ and $n=3,570$ & $\begin{array}{l}\text { Mandatory salt } \\
\text { iodization } \\
(13 \mu \mathrm{g} / \mathrm{g})\end{array}$ & $\begin{array}{l}\text { TSH and prevalence } \\
\text { of thyroid dysfunction }\end{array}$ & $\begin{array}{l}\text { Higher TSH level after } \\
\text { iodization in both regions and across } \\
\text { age groups. Lower } \\
\text { prevalence of mild hyperthyroidism } \\
\text { and increased prevalence of } \\
\text { hypothyroidism related to a higher } \\
\text { iodine intake. }\end{array}$ & B & $\begin{array}{l}\text { Increased iodine intake after } \\
\text { mandatory iodization change } \\
\text { the pattern of thyroid } \\
\text { dysfunction in the population. }\end{array}$ \\
\hline
\end{tabular}

$\mathrm{UIC}=$ urinary iodine concentration, $\mathrm{FFQ}=$ food frequency questionnaire, $\mathrm{TSH}=$ thyroid-stimulating hormone. 
Table 7. Iodine status: Studies from the Nordic countries published in year 2000-2010

\begin{tabular}{|c|c|c|c|c|c|c|}
\hline $\begin{array}{l}\text { Country, author, year } \\
\text { (reference number) }\end{array}$ & Location, year of study & Method & $\begin{array}{c}\text { Number of } \\
\text { subjects and gender }\end{array}$ & Age (years) & $\begin{array}{l}\text { lodine excretion and } \\
\text { thyroid function }\end{array}$ & lodine intake \\
\hline $\begin{array}{l}\text { Denmark, Rasmussen } \\
\text { et al. } 2008 \text { (39) }\end{array}$ & $\begin{array}{l}\text { Aalborg and Copenhagen } \\
\text { 1997-1998 and } \\
2004-2005 .\end{array}$ & $\begin{array}{l}\text { FFQ, spot urine and } \\
\text { estimated } 24 \mathrm{~h} \text { I excretion }\end{array}$ & $\begin{array}{l}4,649 \text { subjects in } 1997-1998 \\
\text { (before fortification) and } 3,570 \\
\text { comparable subjects in } \\
2004-2005 \text { (after fortification). }\end{array}$ & $18-65$ & 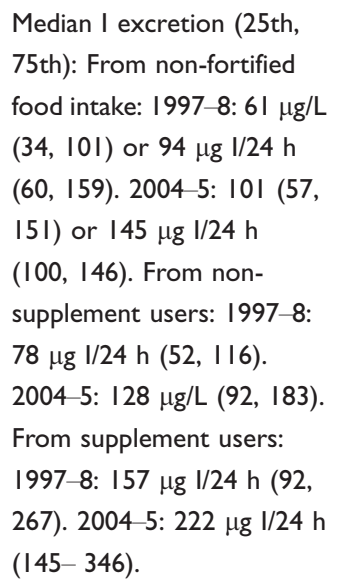 & $\begin{array}{l}\text { Median I intake }(25 \text { th, } 75 \text { th) } \\
\text { from non-fortified food: } 1997- \\
8: 109 \mu g / \text { day }(79,149) .2004 \\
5: \text { I } 10 \mu g / \text { day }(82,146) \text {. Milk } \\
\text { was the strongest determinant } \\
\text { of I intake. }\end{array}$ \\
\hline $\begin{array}{l}\text { Iceland, Gunnarsdottir } \\
\text { et al. } 2010 \text { (48) }\end{array}$ & $\begin{array}{l}\text { Reykjavik, June } \\
\text { 2007-2008 }\end{array}$ & $\begin{array}{l}\text { FFQ as personal interview, } \\
\text { spot urine and blood. }\end{array}$ & II 2 adolescent girls & Born 1987-1992 & $\begin{array}{l}\text { Median } 200 \mu g / L \text { ( } 20 \text { th was } \\
90 \text { and } 80 \text { th was } 320) . \\
\text { Average TSH of } 2.0 \pm 1.2 \\
\mathrm{mU} / \mathrm{L} .\end{array}$ & $\begin{array}{l}\text { Average dietary I intake was } \\
170 \mu \mathrm{g} / \text { day. } 10 \% \text { had I intake } \\
\text { below } 70 \mu \mathrm{g} \text { and none was } \\
\text { above } 600 \mu \mathrm{g} \text {. (Milk and dairy } \\
\text { products provided } 43 \% \text {, fish } \\
24 \% \text { and supplements } 9 \% \text { of the } \\
\text { total dietary I). }\end{array}$ \\
\hline $\begin{array}{l}\text { Norway, Brantsæter } \\
\text { et al. } 2007 \text { (10) }\end{array}$ & $\begin{array}{l}\text { Pregnant women } \\
\text { in MoBa study at Bærum } \\
\text { Hospital. }\end{array}$ & $\begin{array}{l}\text { FFQ, 4-day weighed food } \\
\text { record and } 24-\mathrm{h} \text { urine sample. }\end{array}$ & 119 women & $\begin{array}{l}23-44, \text { mean } \\
\text { age of } 31 .\end{array}$ & $\begin{array}{l}\text { Supplement users FFQ: UI } \\
\text { of } 180 \pm 75 \text { and median } 190 \\
\mu g / 24 \text { h. Supplement users } \\
\text { food diary: UI } 220 \pm 110 \text { and } \\
\text { median } 220 \mu g / 24 \text { h. Non- } \\
\text { supplement users: Ul } 140 \pm \\
90, \text { median II } 10 \mu g / 24 \text { h. }\end{array}$ & $\begin{array}{l}\text { Supplement users: FFQ I intake } \\
\text { of } 21 \mathrm{I} \pm 86 \text {, range } 106-526 \mu \mathrm{g} / \\
\text { day. Food diary I intake of } \\
214 \pm 64 \text {, range } 103-355 \mu \mathrm{g} / \\
\text { day, Non-supplement users: } \\
\text { FFQ I intake of I } 38 \pm 38 \text {, range } \\
25-340 \mu \mathrm{g} / \text { day. Food diary I } \\
\text { intake of II } \pm 42 \text { and range } \\
42-222 \mu \mathrm{g} / \text { day. }\end{array}$ \\
\hline $\begin{array}{l}\text { Norway, Dahl et al. } \\
2003 \text { (50) }\end{array}$ & $\begin{array}{l}\text { Troms } \varnothing, 1999 \text { and } \\
\text { Bergen, } 2001\end{array}$ & Casual urine $\mathrm{TSH}$ and free $\mathrm{T}_{4}$ & $\begin{array}{l}32 \text { men and } 28 \text { women } \\
\text { in Tromsø. } 9 \text { men and } 35 \\
\text { women in Bergen. }\end{array}$ & $\begin{array}{l}23-64 \text { in Troms } \varnothing \\
\text { and } 2 \mathrm{I}-49 \text { in Bergen. }\end{array}$ & 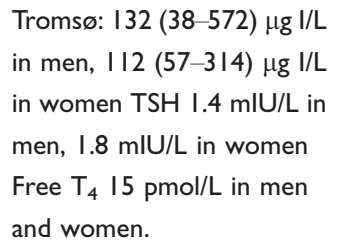 & $\begin{array}{l}\text { Tromsø: Men I } 87 \text { and women } \\
\text { I } 44 \mu \mathrm{g} \text { /day. Bergen: Men I47 } \\
\text { and women } 75 \mu \mathrm{g} \text { I/day. }\end{array}$ \\
\hline
\end{tabular}




\begin{tabular}{|c|c|c|c|c|c|c|}
\hline $\begin{array}{l}\text { Country, author, year } \\
\text { (reference number) }\end{array}$ & Location, year of study & Method & $\begin{array}{c}\text { Number of } \\
\text { subjects and gender }\end{array}$ & Age (years) & $\begin{array}{l}\text { lodine excretion and } \\
\text { thyroid function }\end{array}$ & lodine intake \\
\hline & & & & & 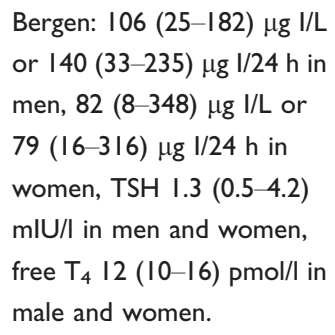 & \\
\hline $\begin{array}{l}\text { Sweden, Anderson } \\
\text { et al. } 2009 \text { (46) }\end{array}$ & $\begin{array}{l}\text { Representative national } \\
\text { samples collected } \\
\text { between Oct } 2006 \text { and } \\
\text { May } 2007 .\end{array}$ & Spot urine & $\begin{array}{l}857 \text { school aged children. } 445 \\
\text { boys and } 412 \text { girls. }\end{array}$ & $6-12$ & $\begin{array}{l}\text { Median UIC was } 125 \mu \mathrm{g} / \mathrm{L} \text {, } \\
\text { range } \mathrm{II}-757.36 \% \text { had } \\
<100 \mu \mathrm{g} / \mathrm{L}, 3 \% \text { had }>300 \\
\mu \mathrm{g} / \mathrm{L} .\end{array}$ & NA \\
\hline $\begin{array}{r}\text { Sweden, Milakovic } \\
\text { et al. } 2004 \text { (47) }\end{array}$ & $\begin{array}{l}\text { Semi-rural community } \\
\text { (Mölnlycke) }\end{array}$ & Spot urine Thyroid volume & $\begin{array}{l}\text { Group I: } 38 \text { boys and } 23 \text { girls. } \\
\text { Group 2: } 12 \text { boys and } 38 \text { girls. } \\
\text { Group 3: } 57 \text { adults }\end{array}$ & $\begin{array}{c}\text { Group 1: 7-9. Group } \\
\text { 2: 15-17. Group 3: } \\
60-65 .\end{array}$ & $\begin{array}{l}\text { Median urinary iodine } \\
\text { concentration was in group } \\
\mathrm{I}: \text { I } 94 \mu \mathrm{g} / \mathrm{L} \text {, group 2: } 246 \\
\mu \mathrm{g} / \mathrm{L} \text { and group 3: } 190 \mu \mathrm{g} / \mathrm{L} \text {. } \\
\text { Median (range) of thyroid } \\
\text { volume was in group I: } 4.7 \\
\mathrm{~mL}(2.9-17) \text {, in group 2: } \\
\text { II.5 } \mathrm{mL}(5.6-32) \text { and in } \\
\text { group 3: I4.3 } \mathrm{mL}(3 . \mathrm{I}-33) \text {. }\end{array}$ & NA \\
\hline
\end{tabular}

$\mathrm{FFQ}=$ food frequency questionnaire, I =iodine, TSH = thyroid-stimulating hormone, UIC = urinary iodine concentration, T4 =thyroxine. 
the Danish iodine supplementation program, which prospectively measure the incidence rates of hyper- and hypothyroidism in the cities of Aalborg and Copenhagen. In the first examination in 1997-98, the Aalborg area was found to be in the range of moderate iodine deficiency, whereas the area around Copenhagen had mild iodine deficiency (38). The difference in iodine intake in these two areas can mainly be explained by the difference in iodine content in drinking water $(5 \mu \mathrm{g} / \mathrm{L}$ in Aalborg and $18 \mu \mathrm{g} / \mathrm{L}$ in Copenhagen) (39). In 2000, it became mandatory to fortify all salts used in bread and household with iodine at a level of $13 \mu \mathrm{g} / \mathrm{g}$. In 2004-2005, the urinary iodine excretion had increased significantly in all age groups compared with before mandatory iodine fortification in both areas. For instance, the medianestimated 24-h urinary iodine excretion in both areas was $78 \mu \mathrm{g} /$ day before iodization and $140 \mu \mathrm{g} /$ day after iodization among non-supplement users. The corresponding median UIC in both areas increased from $61 \mu \mathrm{g} / \mathrm{L}$ in $1997-1999$ to $101 \mu \mathrm{g} / \mathrm{L}$ in 2004-2005 (39). However, the iodine intake in the youngest age groups in both cities and in women aged 40-45 years in the Aalborg area was still below the recommendation after the mandatory iodization of salt (39). Milk, water, and salt intake were determinants of iodine intake in 2004-2005, whereas bread and fish intake were not related with iodine intake (39).

Associations between iodine status and thyroid function The studies from Denmark based on the DanThyr programme shows marked differences in pattern of thyroid dysfunction with different iodine intakes (40, 41) and the optimal level of iodine intake to prevent thyroid disease may be a relatively narrow range around the recommended daily iodine intake of $150 \mu \mathrm{g}$ (42). In general, mild and moderate iodine deficiency is associated with more hyperthyroidism and less hypothyroidism than high iodine intake (42). In 1997-1998, the incidence rate of hyperthyroidism was higher in the Aalborg area with moderate iodine deficiency (with UI of $45 \mu \mathrm{g} / \mathrm{L}$ ) compared with the Copenhagen area with higher iodine intake (mild iodine deficiency) (with UIC of $61 \mu \mathrm{g} / \mathrm{L})(38)$. Further, hyper- and hypothyroidism were more common in females than in males in both areas, and the incidence rates of both hyper- and hypothyroidism increased with age. In the Copenhagen area, a higher incidence rate of hypothyroidism was found compared with the Aalborg area.

Even the small differences in UIC from mild $(61 \mu \mathrm{g} / \mathrm{L})$ and moderate $(45 \mu \mathrm{g} / \mathrm{L})$ iodine deficiency areas in Denmark showed marked differences in the prevalence of goiter with $9.8 \%$ goiter in the mild iodine deficiency area (Copenhagen) and $14.6 \%$ goiter in the moderate iodine deficiency area (Aalborg) $(43,44)$.
A lower TV was seen in all age groups independent of sex after iodization and the decline was largest in the Aalborg area with former moderate iodine deficiency (40). The level of TSH was also found to increase from $1.30 \mathrm{mUI} / \mathrm{L}$ to $1.51 \mathrm{mUI} / \mathrm{L}$ in both regions and across age groups after the introduction of iodization of salt (41). The increase was expected as populations with iodine sufficiency in general have a higher level of TSH than populations with iodine deficiency (41). The effect of smoking on hormonal levels of TSH and free $\mathrm{T}_{4}$ were unchanged after the iodization, however, increased iodine intake had an effect on the TV of smokers, as the difference in TV between heavy smokers and nonsmokers was reduced after iodization of salt (45).

lodine status: studies from other Nordic countries

A cross-sectional study of Swedish national data on UIC of children aged 6-12 years indicated adequate iodine nutrition, and there were no gender or age differences in median UIC of the children (46). This study provides evidence that the voluntary addition of iodine to salt since 1,936 at a level of $40-70 \mathrm{mg} / \mathrm{kg}$ is sufficient to ensure adequate iodine nutrition in the Swedish population (46). Iodized table salt remains the main dietary source of iodine in the diet and among adults it is estimated to provide more than $50 \%$ of the iodine intake in Sweden (46). In another Swedish cross-sectional study among small groups of children, teenagers, and adults, the median UIC suggested adequate iodine nutrition (47).

A cross-sectional study including adolescent girls from Iceland found optimal iodine status; however, the result should be used with cation, as only $39 \%$ completed the study. Still the results are good estimates of the iodine nutrition of adolescent girls from Iceland (48).

Results from a representative study in Norway suggest that the dietary iodine intake is in the range considered to be sufficient among adults and children; however, it decreased among adolescents, especially among girls (49). Regular intake of milk, dairy products, and seafood are of importance to secure adequate iodine intake in Norway as the iodization of salt (only table salt) is very low $(5 \mu \mathrm{g} / \mathrm{g})$. This was clearly shown in the study including subjects with a variable intake of fish and dairy products, which indicated mild iodine deficiency among subjects having low intake of these two food groups (50).

\section{Discussion}

Iodine deficiency remains a major threat to the health and development of populations around the world, and it is claimed that much of Europe is iodine deficient (51). The iodine status in all the Nordic countries is not well documented; however, based on UIC, the iodine nutrition status in Denmark, Iceland, Finland, and Sweden is sufficient and it is deficient in Norway according to WHO data (51). 
The overall aim was to review recent scientific data on health effects of iodine status (as an indicator of iodine intake) in order to update current Nordic dietary reference values and to assess the scientific evidence and special relevance for the Nordic setting by increasing the RDI of iodine during pregnancy and lactation from what was presented in the 4th edition of NNR.

Grading of evidence is presented in Table 8. It should be emphasized that the grading of evidence is only based on studies from 2000-2010 and in some cases inclusion of earlier studies might have resulted in different grading. Evidence supporting that iodine supplementation during pregnancy is associated with maternal iodine status and thyroid function is suggestive $(7,9)$. One A study and one B study showed improved cognitive function of infants and children up to 18 months with potential indicators of improved iodine status of the mother $(15,16)$, while the evidence for improved cognitive function in older children is limited. It should be noted that no direct measurements of iodine intake where used in these studies $(15,16)$, and the conclusions are therefore based on the association between thyroid function (as an indicator of iodine status) and cognitive function of the offspring. The relevance of these studies to be used to set recommendations on iodine intake might therefore be questioned. Moderately to severely iodine-deficient children (6-13 years) will probably benefit from iodine supplementation or improved iodine status in order to improve cognitive function (2325,31 ), while only one study showed improved cognitive function with iodine supplementation in children from a mildly iodine-deficient area (23). No conclusions can be drawn related to other outcomes included in our search. A second literature search (using the same search string as previously) was conducted in March 2012, including

Table 8. Grading of evidence

\begin{tabular}{|c|c|c|c|}
\hline & $\begin{array}{l}\text { Grading of } \\
\text { evidence* }\end{array}$ & $\begin{array}{l}\text { Number of } \\
\text { studies }\end{array}$ & References \\
\hline $\begin{array}{l}\text { lodine supplementation during pregnancy is related } \\
\text { to improved maternal iodine status and/or thyroid } \\
\text { function. }\end{array}$ & Suggestive & Two B studies & $\begin{array}{l}\text { Antonangeli et al. } 2002 \text { (7); Nøhr \& Laurberg, } \\
2000 \text { (9) }\end{array}$ \\
\hline $\begin{array}{l}\text { lodine supplementation during pregnancy is related } \\
\text { to infant thyroid function. }\end{array}$ & No conclusion & One B study & Nøhr \& Laurberg, 2000 (9) \\
\hline $\begin{array}{l}\text { lodine supplementation of pregnant women with } \\
\text { thyroid peroxidase antibodies (TPO-Ab) is not } \\
\text { associated with adverse effects. }\end{array}$ & No conclusion & One A study & Nøhr et al., 2000 (8) \\
\hline $\begin{array}{l}\text { Improved prenatal iodine status is associated with } \\
\text { improved cognitive function of infants and children } \\
\text { up to } 18 \text { months. }\end{array}$ & Suggestive & $\begin{array}{l}\text { One A study and } \\
\text { two B studies }\end{array}$ & $\begin{array}{l}\text { Oken et al. } 2009 \text { (16); Choudhury \& Gorman } \\
2003 \text { (I5) }\end{array}$ \\
\hline $\begin{array}{l}\text { Improved prenatal iodine status is associated } \\
\text { with improved cognitive function in children above } 2 \\
\text { years. }\end{array}$ & No conclusion & One A study & Oken et al. 2009 (16) \\
\hline $\begin{array}{l}\text { lodine supplementation improves iodine status in } \\
\text { mildly, moderately and severe iodine-deficient } \\
\text { children (7-13 years). }\end{array}$ & Probable & Four B studies & $\begin{array}{l}\text { Gordon et al., } 2009 \text { (23); Zimmermann et al., } 2006 \\
\text { (24); van den Briel et al., } 2000 \text { (25); Zimmerman } \\
\text { et al., } 2009 \text { (3l). }\end{array}$ \\
\hline $\begin{array}{l}\text { lodine supplementation or improved iodine status } \\
\text { improves cognitive function in moderately to severe } \\
\text { iodine-deficient children aged } 6-13 \text { years. }\end{array}$ & Probable & Three B studies & $\begin{array}{l}\text { Gordon et al., } 2009 \text { (23); Zimmermann et al., } 2006 \\
\text { (24); van den Briel et al., } 2000 \text { (25) }\end{array}$ \\
\hline $\begin{array}{l}\text { lodine supplementation improves cognitive function in } \\
\text { mildly iodine-deficient children aged } 10-13 \text { years }\end{array}$ & No conclusion & One B study & Gordon et al., 2009 (23) \\
\hline $\begin{array}{l}\text { lodine supplementation is related to improved lipid } \\
\text { profile in children }\end{array}$ & No conclusion & One B study & Zimmerman et al., 2009 (3I) \\
\hline $\begin{array}{l}\text { lodine status of adults is associated with features } \\
\text { of the metabolic syndrome. }\end{array}$ & No conclusion & One B study & Ayturk et al., 2009 (32) \\
\hline $\begin{array}{l}\text { lodine status is related to risk of prostate } \\
\text { cancer. }\end{array}$ & No conclusion & One B study & Hoption Cann et al., 2007 (33) \\
\hline $\begin{array}{l}\text { Excessive intake of iodine (UIC } 300-500 \text { or }>500 \mathrm{mcg} / \\
\text { L) is associated with adverse effects in children. }\end{array}$ & No conclusion & One B study & Zimmermann et al., 2005 (34) \\
\hline
\end{tabular}

*Using the criteria for assigning grade of evidence presented in the WCRF cancer report, introduced in the SLR guide for the 5th edition of NNR. 
studies published in the period October 2010 to February 2012. No additional studies were included in this review, as it would not modify the conclusions drawn from the studies included.

Surprisingly, dietary data was only included in a very low number of studies. Furthermore, in many cases the exposure was thyroid function rather than estimate of iodine intake (i.e. UIC). Definitions of severe, moderate, and mild iodine deficiency also vary between studies. It is therefore challenging to use information from the studies included in this review in order to set dietary reference values.

\section{Conclusions}

There are no new data supporting changes in dietary reference values for children or adults. Although the WHO/UNICEF/ICCIDD has increased the RDI for iodine from 200 to $250 \mu \mathrm{g} /$ day in pregnancy and in lactating women (6), they emphasized the need for more data on the level of iodine intake that ensures maternal and newborn euthyroidism. The iodine requirement during pregnancy is increased because the mother synthesizes $\sim 50 \%$ more iodine-containing thyroid hormones to maintain maternal euthyroidism and to transfer thyroid hormones to the fetus and because the mother has increased renal losses of iodine (3). The rationale for increasing the dietary reference values for pregnant and lactating women in the 5th edition of NNR needs to be discussed in a broad perspective taking into account iodine status of pregnant women in the Nordic countries. Nordic studies retrieved have mainly described the thyroid function rather than the intake and sources of iodine in the diet. Further studies are required, especially among the most vulnerable groups, but also studies which assess possible adverse effects of high intake of iodine.

\section{Acknowledgements}

Special thanks to Sveinn Olafsson, Jannes Engquist, Ulla-Kaisa Koivisto Hursti, and Wulf Becker for their help and guidance throughout the whole process.

\section{Conflict of interest and funding}

The authors have not received any funding or benefits from industry or elsewhere to conduct this study.

\section{References}

1. FAO/WHO. Vitamin and mineral requirements in human nutrition, 2nd ed. Geneva: World Health Organization, 2005. http://whqlibdoc.who.int/publications/2004/9241546123.pdf

2. WHO (World Health Organization). Iodine deficiency in Europe. A continuing public health problem. 2007. Geneva: World Health Organization.
3. WHO/UNICEF/ICCIDD. Assessment of the iodine deficiency disorders and monitoring their elimination. A Guide for program managers. Geneva: World Health Organization; 2008.

4. Nordic Nutrition Recommendations 2004. Integrating nutrition and physical activity. 4th ed. Nordic Council of Ministers. Denmark: Arhus; 2005.

5. Food and Nutrition Board: Institute of Medicine. Dietary reference intakes for vitamin $\mathrm{A}$, vitamin $\mathrm{K}$, arsenic, boron, chromium, copper, iodine, iron, manganese, molybdenum, nickel, silicon, vanadium and zinc. Washington, DC: National Academy Press; 2001.

6. WHO/UNICEF. Reaching optimal iodine nutrition in pregnant and lactating women and young children. Joint statement of the World Health Organization and the United Nations Children's Fund. Geneva, Switzerland: World Health Organization; 2007.

7. Antonangeli L, Maccherini D, Cavaliere R, Di Giulio C, Reinhardt B, Pinchera A, et al. Comparison of two different doses of iodide in the prevention of gestational goiter in marginal iodine deficiency: a longitudinal study. Eur J Endocrinol 2002; 147: 29-34.

8. Nøhr SB, Jørgensen A, Pedersen KM, Laurberg P. Postpartum thyroid dysfunction in pregnant thyroid peroxidase antibodypositive women living in an area with mild to moderate iodine deficiency: is iodine supplementation safe? J Clin Endocrinol Metab 2000; 85: 3191-8.

9. Nøhr SB, Laurberg P. Opposite variations in maternal and neonatal thyroid function induced by iodine supplementation during pregnancy. J Clin Endocrinol Metab 2000; 85: 623-7.

10. Brantsaeter AL, Haugen M, Hagve TA, Aksnes L, Rasmussen SE, Julshamn K, et al. Self-reported dietary supplement use is confirmed by biological markers in the Norwegian Mother and Child Cohort Study (MoBa). Ann Nutr Metab 2007; 51: 146-54.

11. Alvarez-Pedrerol M, Guxens M, Mendez M, Canet Y, Martorell $\mathrm{R}$, Espada M, et al. Iodine levels and thyroid hormones in healthy pregnant women and birth weight of their offspring. Eur J Endocrinol 2009; 160: 423-9.

12. Dillon JC, Milliez J. Reproductive failure in women living in iodine deficient areas of West Africa. BJOG 2000; 107: 631-6.

13. Borekci B, Gulaboglu M, Gul M. Iodine and magnesium levels in maternal and umbilical cord blood of preeclamptic and normal pregnant women. Biol Trace Elem Res 2009; 129: 1-8.

14. Bodzek P, Olejek A, Zamlynski J. Iodine excretion with urine and thyrotrophic hormone concentration in normal and complicated pregnancies in the industrial region of iodine deficiency. Wiad Lek 2006; 59: 612-7.

15. Choudhury N, Gorman KS. Subclinical prenatal iodine deficiency negatively affects infant development in Northern China. J Nutr 2003; 133: 3162-5.

16. Oken E, Braverman LE, Platek D, Mitchell ML, Lee SL, Pearce EN. Neonatal thyroxine, maternal thyroid function, and child cognition. J Clin Endocrinol Metab 2009; 94: 497-503.

17. Berbel P, Mestre JL, Santamaría A, Palazón I, Franco A, Graells $\mathrm{M}$, et al. Delayed neurobehavioral development in children born to pregnant women with mild hypothyroxinemia during the first month of gestation: the importance of early iodine supplementation. Thyroid 2009; 19: 511-9.

18. Velasco I, Carreira M, Santiago P, Muela JA, García-Fuentes E, Sánchez-Muñoz B, et al. Effect of iodine prophylaxis during pregnancy on neurocognitive development of children during the first two years of life. J Clin Endocrinol Metab 2009; 94: $3234-41$.

19. O'Donnell KJ, Rakeman MA, Zhi-Hong D, Xue-Yi C, Mei ZY, DeLong $\mathrm{N}$, et al. Effects of iodine supplementation during 
pregnancy on child growth and development at school age. Dev Med Child Neurol 2002; 44: 76-81.

20. Laurberg P, Nøhr SB, Pedersen KM, Fuglsang E. Iodine nutrition in breast-fed infants is impaired by maternal smoking. J Clin Endocrinol Metab 2004; 89: 181-7.

21. Skeaff SA, Ferguson EL, McKenzie JE, Valeix P, Gibson RS, Thomson CD. Are breast-fed infants and toddlers in New Zealand at risk of iodine deficiency? Nutrition 2005; 21: 325-31.

22. Chan SS, Hams G, Wiley V, Wilcken B, McElduff A. Postpartum maternal iodine status and the relationship to neonatal thyroid function. Thyroid 2003; 13: 873-6.

23. Gordon RC, Rose MC, Skeaff SA, Gray AR, Morgan KM, Ruffman $\mathrm{T}$. Iodine supplementation improves cognition in mildly iodine-deficient children. Am J Clin Nutr 2009; 90: 1264-71.

24. Zimmermann MB, Connolly K, Bozo M, Bridson J, Rohner F, Grimci L. Iodine supplementation improves cognition in iodinedeficient schoolchildren in Albania: a randomized, controlled, double-blind study. Am J Clin Nutr 2006; 83: 108-14.

25. van den Briel $\mathrm{T}$, West $\mathrm{CE}$, Bleichrodt $\mathrm{N}$, van de Vijver FJ, Ategbo EA, Hautvast JG. Improved iodine status is associated with improved mental performance of schoolchildren in Benin. Am J Clin Nutr 2000; 72: 1179-85.

26. Santiago-Fernandez P, Torres-Barahona R, Muela-Martínez JA, Rojo-Martínez G, García-Fuentes E, Garriga MJ, et al. Intelligence quotient and iodine intake: a cross-sectional study in children. J Clin Endocrinol Metab 2004; 89: 3851-7.

27. Soriguer F, Millón MC, Muñoz R, Mancha I, López Siguero JP, Martinez Aedo MJ, et al. The auditory threshold in a school-age population is related to iodine intake and thyroid function. Thyroid 2000; 10: 991-9.

28. Boyanov MA, Temelkova NL, Popivanov PP. Determinants of thyroid volume in schoolchildren: fat-free mass versus body fat mass-a cross-sectional study. Endocr Pract 2004; 10: 409-16.

29. Kaloumenou I, Duntas LH, Alevizaki M, Mantzou E, Chiotis $\mathrm{D}$, Mengreli C, et al. Gender, age, puberty, and BMI related changes of TSH and thyroid hormones in schoolchildren living in a long-standing iodine replete area. Horm Metab Res 2010; 42: $285-9$.

30. Ozön A, Alikaşifoğlu A, Yordam N. Influence of iodine supplementation on serum insulin-like growth factor-I (IGF-I) and IGF-binding protein-3 (IGFBP-3) levels in severe iodine deficiency. Turk J Pediatr 2004; 46: 303-8.

31. Zimmermann MB, Aeberli I, Melse-Boonstra A, Grimci L, Bridson J, Chaouki N, et al. Iodine treatment in children with subclinical hypothyroidism due to chronic iodine deficiency decreases thyrotropin and C-peptide concentrations and improves the lipid profile. Thyroid 2009; 19: 1099-104.

32. Ayturk S, Gursoy A, Kut A, Anil C, Nar A, Tutuncu NB. Metabolic syndrome and its components are associated with increased thyroid volume and nodule prevalence in a mild-tomoderate iodine-deficient area. Eur J Endocrinol 2009; 161: 599-605.

33. Hoption Cann SA, Qiu Z, van Netten C. A prospective study of iodine status, thyroid function, and prostate cancer risk: followup of the First National Health and Nutrition Examination Survey. Nutr Cancer 2007; 58: 28-34.

34. Zimmermann MB, Ito Y, Hess SY, Fujieda K, Molinari L. High thyroid volume in children with excess dietary iodine intakes. Am J Clin Nutr 2005; 81: 840-4.

35. Yang F, Shan Z, Teng X, Li Y, Guan H, Chong W, et al. Chronic iodine excess does not increase the incidence of hyperthyroidism: a prospective community-based epidemiological survey in China. Eur J Endocrinol 2007; 156: 403-8.

36. Alsayed A, Gad AM, Abdel-Baset H, Abdel-Fattah A, Ahmed A, Azab A. Excess urinary iodine is associated with autoimmune subclinical hypothyroidism among Egyptian women. Endocr J 2008; 55: 601-5.

37. Guan H, Li C, Li Y, Fan C, Teng Y, Shan Z, et al. High iodine intake is a risk factor of post-partum thyroiditis: result of a survey from Shenyang, China. J Endocrinol Invest 2005; 28: 876-1.

38. Pedersen IB, Laurberg P, Arnfred T, Knudsen N, Jørgensen T, Perrild $\mathrm{H}$, et al. Surveyance of disease frequency in a population by linkage to diagnostic laboratory databases. A system for monitoring the incidences of hyper- and hypothyroidism as part of the Danish iodine supplementation program. Comput Methods Programs Biomed 2002; 67: 209-16.

39. Rasmussen LB, Carlé A, Jørgensen T, Knudsen N, Laurberg P, Pedersen IB, et al. Iodine intake before and after mandatory iodization in Denmark: results from the Danish Investigation of Iodine Intake and Thyroid Diseases (DanThyr) study. Br J Nutr 2008; 100: 166-73.

40. Vejbjerg P, Knudsen N, Perrild H, Carlé A, Laurberg P, Pedersen IB, et al. Effect of a mandatory iodization program on thyroid gland volume based on individuals' age, gender, and preceding severity of dietary iodine deficiency: a prospective, population-based study. J Clin Endocrinol Metab 2007; 92: $1397-401$.

41. Vejbjerg P, Knudsen N, Perrild H, Laurberg P, Carlé A, Pedersen IB, et al. Lower prevalence of mild hyperthyroidism related to a higher iodine intake in the population: prospective study of a mandatory iodization programme. Clin Endocrinol (Oxf) 2009; 71: 440-5.

42. Bülow Pedersen I, Knudsen N, Jørgensen T, Perrild H, Ovesen $\mathrm{L}$, Laurberg P. Large differences in incidences of overt hyperand hypothyroidism associated with a small difference in iodine intake: a prospective comparative register-based population survey. J Clin Endocrinol Metab 2002; 87: 4462-9.

43. Knudsen N, Bülow I, Jørgensen T, Laurberg P, Ovesen L, Perrild H. Comparative study of thyroid function and types of thyroid dysfunction in two areas in Denmark with slightly different iodine status. Eur J Endocrinol 2000; 143: $485-91$.

44. Knudsen N, Bülow I, Jorgensen T, Laurberg P, Ovesen L, Perrild H. Goitre prevalence and thyroid abnormalities at ultrasonography: a comparative epidemiological study in two regions with slightly different iodine status. Clin Endocrinol (Oxf) 2000; 53: 479-85.

45. Vejbjerg P, Knudsen N, Perrild H, Carlé A, Laurberg P, Pedersen IB, et al. The impact of smoking on thyroid volume and function in relation to a shift towards iodine sufficiency. Eur J Epidemiol 2008; 23: 423-9.

46. Andersson M, Berg G, Eggertsen R, Filipsson H, Gramatkovski $\mathrm{E}$, Hansson M, et al. Adequate iodine nutrition in Sweden: a cross-sectional national study of urinary iodine concentration in school-age children. Eur J Clin Nutr 2009; 63: 828-34.

47. Milakovic M, Berg G, Nyström E, Lindstedt G, Gebre-Medhin M, Eggertsen R. Urinary iodine and thyroid volume in a Swedish population. J Intern Med 2004; 255: 610-4.

48. Gunnarsdottir I, Gunnarsdottir BE, Steingrimsdottir L, Maage A, Johannesson AJ, Thorsdottir I. Iodine status of adolescent girls in a population changing from high to lower fish consumption. Eur J Clin Nutr 2010; 64: 958-64.

49. Dahl L, Johansson L, Julshamn K, Meltzer HM. The iodine content of Norwegian foods and diets. Public Health Nutr 2004; 7: 569-76. 
50. Dahl L, Meltzer HM, Opsahl JA, Julshamn K. Iodine intake and status in two groups of Norwegians. Scand J Nutr 2003; 47: $170-8$.

51. Zimmermann MB, Andersson M. Prevalence of iodine deficiency in Europe in 2010. Ann Endocrinol (Paris) 2011; 72: $164-6$.

\section{Appendix I}

Search terms

Date: September 2010

Database: PubMed/Medline

(Humans[MeSH Terms]) OR human*[Title/Abstract]

lodine[MeSH Terms]
*Ingibjörg Gunnarsdottir

Unit for Nutrition Research

University of Iceland and Landspitali The National University Hospital of Iceland

Eiriksgata 29, IS-I0I Reykjavik, Iceland

Email: ingigun@hi.is

Growth and development[Title/Abstract]) OR Thyroid gland[MeSH Terms]) OR Thyroid gland size[Title/Abstract]) OR Thyroid hormones[MeSH Terms]) OR Metabolism[Title/Abstract]) OR Hyperthyroidism[MeSH Terms]) OR Hypothyroidism[MeSH Terms]) OR Overweight[Title/Abstract]) OR Obesity[MeSH Terms]) OR Pregnancy[MeSH Terms]) OR pregnancy*[Title/ Abstract]) OR Life style[Title/Abstract]) OR excessive[Title/Abstract]) OR insufficient[Title/Abstract]) OR iron[MeSH Terms]) OR selenium[MeSH Terms]) OR Urinary iodine concentration[Title/Abstract]) OR lodine status[Title/Abstract]) OR Maternal lodine intake[Title/Abstract]) OR Neonatal TSH[Title/Abstract]) OR cognition[Title/Abstract]) OR child development[MeSH Terms]) OR Child development[Title/Abstract]) OR infant development[Title/Abstract]) OR maternal iodine status[Title/Abstract]]

(1504 hits)

Search terms

Date: September 2010

Database: SveMed+ lodine[MeSH Terms]

( 12 hits)

Appendix 2.

\section{Article}

Reason for exclusion

(2003). "lodine deficiency in Europe. National reports on iodine status in

Overview.

West-Central European countries. First symposium of ICCIDD West-Central

Europe. Goteborg, Sweden, September 7, 2002." J Endocrinol Invest 26(9

Suppl): $1-62$.

Ainy, E., et al. (2007). "Assessment of intertrimester and seasonal variations of Not relevant, only describing the status, no other outcome or food. urinary iodine concentration during pregnancy in an iodine-replete area." Clin From Iran.

Endocrinol (Oxf) 67(4): 577-58I.

Alikasifoglu, A., et al. (2002). "Serum insulin-like growth factor-I (IGF-I) and Cross sectional, the follow up is presented in Özon 2004.

IGF-binding protein-3 levels in severe iodine deficiency." Turk J Pediatr 44(3):

2I5-218.

Alvarez-Pedrerol, M., et al. (2009). "Organochlorine compounds, iodine

Not relevant to the research questions.

intake, and thyroid hormone levels during pregnancy." Environ Sci Technol

43(20): 7909-79|5.

Alvarez-Pedrerol, M., et al. (2010). "lodine sources and iodine levels in

Cross-sectional. pregnant women from an area without known iodine deficiency." Clin

Endocrinol (Oxf) 72(I): 8I-86.

Aminorroaya, A., et al. (2004). "lodine repletion, thyrotoxicosis and atrial $\quad$ From Iran, case report.

fibrillation in Isfahan, Iran." Ann Saudi Med 24(I): 13-17.

Andersen, S., et al. (200I). "Variations in urinary iodine excretion and thyroid Methodology, includes 16 participants.

function. A I-year study in healthy men." Eur J Endocrinol I44(5): 46I-465. 
Appendix 2 (Continued)

Article

Reason for exclusion

Andersson, M., et al. (2007). "Prevention and control of iodine deficiency in Review.

pregnant and lactating women and in children less than 2-years-old:

conclusions and recommendations of the Technical Consultation." Public

Health Nutr 10(12A): 1606-1611.

Andersson, M., et al. (2010). "Epidemiology of iodine deficiency: Salt iodisation Review.

and iodine status." Best Pract Res Clin Endocrinol Metab 24(I): I-II.

Andersson, M., et al. (2005). "Current global iodine status and progress over Review.

the last decade towards the elimination of iodine deficiency." Bull World

Health Organ 83(7): 518-525.

Andersson, M., et al. (2003). "The WHO Global Database on iodine

Short communication.

deficiency disorders: the importance of monitoring iodine." Scandinavian

Journal of Nutrition 47(4): 162-166.

Andersen, S., et al. (2002). "lodine content of traditional Greenlandic food

items and tap water in East and West Greenland." Int J Circumpolar Health

6I (4): 332-340.

Angermayr, L., et al. (2004). "lodine supplementation for preventing iodine Cochrane review.

deficiency disorders in children." Cochrane Database Syst Rev(2): CD003819.

Aquaron, R., et al. (2002). "Bioavailability of seaweed iodine in human beings." Not relevant for our research questions.

Cell Mol Biol (Noisy-le-grand) 48(5): 563-569.

Ares, S., et al. (2008). "lodine balance, iatrogenic excess, and thyroid

Report from seminars in perinatology.

dysfunction in premature newborns." Semin Perinatol 32(6): 407-4I2.

Ares, S., et al. (2005). "Neonatal iodine deficiency: clinical aspects." J Pediatr Review.

Endocrinol Metab 18 Suppl I: 1257-1264.

Arum, S. M., et al. (2009). "Excess iodine from an unexpected source." N Engl Letter to the editor, case report.

J Med 360(4): 424426.

Azizi, F., et al. (2005). "Reappraisal of the risk of iodine-induced

Observational, population study from Iran, not relevant.

hyperthyroidism: an epidemiological population survey." J Endocrinol Invest

28(I): 23-29.

Azizi, F., et al. (2009). "Breastfeeding and maternal and infant iodine nutrition." Review.

Clin Endocrinol (Oxf) 70(5): 803-809.

Bastemir, M., et al. (2006). "WITHDRAWN: High prevalence of thyroid Withdrawn.

dysfunction and autoimmune thyroiditis in adolescents after elimination of

iodine deficiency in the Eastern Black Sea Region of Turkey." Thyroid 16(12):

|265-127|.

Becker, D. V., et al. (2006). "lodine supplementation for pregnancy and

lactation-United States and Canada: recommendations of the American

Thyroid Association." Thyroid 16(10): 949-95I.

Benton, D. (2010). "The influence of dietary status on the cognitive Review.

performance of children." Mol Nutr Food Res 54(4): 457-470.

Berbel, P., et al. (2007). "lodine supplementation during pregnancy: a public Opinion. Review.

health challenge." Trends Endocrinol Metab 18(9): 338-343.

Berkovski, V. (2002). "New iodine models family for simulation of short-term Methodological aspect, outside our research questions.

biokinetics processes, pregnancy and lactation." Food Nutr Bull 23(3 Suppl):

87-94.

Bernal, J. (2005). "Pathophysiology of thyroid hormone deficiency during fetal Review.

development." J Pediatr Endocrinol Metab 18 SuppI I: I253-1256.

Black, R. E., et al. (2008). "Maternal and child undernutrition: global and Review.

regional exposures and health consequences." Lancet 37 I(9608): 243-260.

Boas, M., et al. (2009). "Association of thyroid gland volume, serum insulin-like

growth factor-I, and anthropometric variables in euthyroid prepubertal

Recommendation of the American Thyroid Association of iodine intake in US and Canada.

children." J Clin Endocrinol Metab 94(I0): 403I-4035.

Cross-sectional with longitudinal data on growth. About thyroid function and not dietary iodine. 
Bonar, B. D., et al. (2000). "Hypothyroidism and aging: the Rosses' survey." Thyroid I0(9): 82I-827.

Borak, J. (2005). "Neonatal hypothyroidism due to maternal vegan diet." J Pediatr Endocrinol Metab 18(6): 621.

Boric, M., et al. (2009). "lodine supplementation in pregnancy." Acta Clin Croat 48(4): 469-473.

Bournaud, C., et al. (2003). "lodine excess and thyroid autoimmunity." J Endocrinol Invest 26(2 Suppl): 49-56.

Brauer, V. F., et al. (2006). "Selenium and goiter prevalence in borderline iodine sufficiency." Eur J Endocrinol I55(6): 807-8I2.

Braverman, L. E. (200I). "The physiology and pathophysiology of iodine and the thyroid." Thyroid II (5): 405.

Brantsaeter, A. L., et al. (2009). "Evaluation of urinary iodine excretion as a biomarker for intake of milk and dairy products in pregnant women in the Norwegian Mother and Child Cohort Study (MoBa)." Eur J Clin Nutr 63(3): 347-354.

Bruce, B., et al. (2003). "Isoflavone supplements do not affect thyroid function in iodine-replete postmenopausal women." J Med Food 6(4): 309-316.

Bulow Pedersen, I., et al. (2006). "Increase in incidence of hyperthyroidism predominantly occurs in young people after iodine fortification of salt in

Denmark." J Clin Endocrinol Metab 9 I (I0): 3830-3834.

Burgi, H. (2010). “lodine excess.” Best Pract Res Clin Endocrinol Metab 24(I): Review.

107-II5.

Burns, R., et al. (2008). "Can neonatal TSH screening reflect trends in population iodine intake?" Thyroid 18(8): 883-888.

Busnardo, B., et al. (2006). "Restricted intraindividual urinary iodine concentration variability in nonfasting subjects." Eur J Clin Nutr 60(3): $42 \mathrm{I}-425$.

Caldwell, K. L., et al. (2005). "Urinary iodine concentration: United States National Health And Nutrition Examination Survey 200I-2002." Thyroid I5(7): 692-699.

Camargo, R. Y., et al. (2008). "Thyroid and the environment: exposure to excessive nutritional iodine increases the prevalence of thyroid disorders in Sao Paulo, Brazil." Eur J Endocrinol I 59(3): 293-299.

Cann, S. A., et al. (2000). "Hypothesis: iodine, selenium and the development Review.

of breast cancer." Cancer Causes Control I I(2): 12I-127.

Carle, A., et al. (2006). "Epidemiology of subtypes of hypothyroidism in

Denmark." Eur J Endocrinol I54(I): 2I-28.

Cerqueira, C., et al. (2009). "Association of iodine fortification with incident Use of antithyroid medication as endpoint after mandatory fortification use of antithyroid medication-a Danish Nationwide Study." J Clin Endocrinol in Denmark.

Metab 94(7): 2400-2405.

Chanoine, J. P. (2003). "Selenium and thyroid function in infants, children and Review.

adolescents." Biofactors 19(3-4): 137-143.

Charnley, G. (2008). "Perchlorate: overview of risks and regulation." Food Chem Toxicol 46(7): 2307-23I5.

Clar, C., et al. (2002). "lodized salt for iodine deficiency disorders. A systematic review." Endocrinol Metab Clin North Am 3I (3): 68I-698.

Dabbaghmanesh, M. H., et al. (2007). "Low serum selenium concentration as a Cross-sectional study, no food, Iran with high goitre prevalence. possible factor for persistent goiter in Iranian school children." Biofactors

29(2-3): 77-82.

de Benoist, B., et al. (2008). "lodine deficiency in 2007: global progress since Review.

2003." Food Nutr Bull 29(3): 195-202.
Descriptive study from Ireland, nothing about iodine intake.

Letter to the editor.

Review.

Review.

Not relevant to the research question.

Guest editorial.

Not related to the research question.

Few participants, about thyroid function and nothing about iodine intake.

Salt fortification and hyperthyroidism. Cases of overt hyperthyroidism in two areas in DK as endpoints.

Methodological aspect, outside our research questions.

Methodological aspect, outside our research questions.

UIC in US from NHANES. Descriptive study.

Only cross-sectional descriptive, without relating UIC to outcomes.

Not relevant to the research questions. Also a review.

Not relevant to the research questions. 
Appendix 2 (Continued)

Article

de Escobar, G. M., et al. (2008). "The changing role of maternal thyroid hormone in fetal brain development." Semin Perinatol 32(6): 380-386.

de Escobar, G. M., et al. (2007). "lodine deficiency and brain development in Review.

the first half of pregnancy." Public Health Nutr I O(I2A): I554-1570.

de Vijlder, J. J. (2003). "Primary congenital hypothyroidism: defects in iodine Prize lecture.

pathways." Eur J Endocrinol I49(4): 247-256.

Delange, F. (2000). "The role of iodine in brain development." Proc Nutr Soc Review.

59(I): 75-79.

Delange, F. (200I). “lodine deficiency as a cause of brain damage.” Postgrad Editorial overview.

Med J 77(906): 217-220.

Delange, F. (2002). "lodine deficiency in Europe and its consequences: an

update.” Eur J Nucl Med Mol Imaging 29 Suppl 2: S404 416.

Delange, F. (2005). "Epidemiology and impact of iodine deficiency in
pediatrics." J Pediatr Endocrinol Metab I 8 Suppl I: I245-I25I.

Delange, F. (2007). "lodine requirements during pregnancy, lactation and the Review.

neonatal period and indicators of optimal iodine nutrition." Public Health

Nutr 10(12A): 157I-1580; discussion 158I-1573.

Delange, F., et al. (2002). "World status of monitoring iodine deficiency

disorders control programs." Thyroid I2(10): 915-924.

Delange, F., et al. (2002). "Determining median urinary iodine concentration that indicates adequate iodine intake at population level." Bull World Health

Organ 80(8): 633-636.

Delange, F., et al. (200I). "lodine deficiency in the world: where do we stand Review.

at the turn of the century?" Thyroid I I(5): 437-447.

Delange, F., et al. (2000). “lodine supplementation: benefits outweigh risks.”
Drug Saf 22(2): 89-95.

Delange, F., et al. (2000). "Silent iodine prophylaxis in Western Europe only partly corrects iodine deficiency; the case of Belgium." Eur J Endocrinol

I43(2): 189-196.

Derwahl, M., et al. (2000). "Multinodular goitre: 'much more to it than simply Review.

iodine deficiency".' Baillieres Best Pract Res Clin Endocrinol Metab I4(4):

$577-600$.

Dorairajan, N., et al. (2002). "A descriptive study of papillary thyroid

carcinoma in a teaching hospital in Chennai, India." Asian J Surg 25(4):

300-303.

Dorea, J. G. (2002). “lodine nutrition and breast feeding.” J Trace Elem Med Review.

Biol I 6(4): 207-220.

Dorey, C. M., et al. (2008). "Reference values for spot urinary iodine

concentrations in iodine-sufficient newborns using a new pad collection method." Thyroid I 8(3): 347-352.

Dorr, M., et al. (2008). "The association of thyroid function with carotid artery plaque burden and strokes in a population-based sample from a previously iodine-deficient area." Eur J Endocrinol I59(2): I45-I52.

Duarte, G. C., et al. (2009). "Excessive iodine intake and ultrasonographic thyroid abnormalities in schoolchildren." J Pediatr Endocrinol Metab 22(4): 327-334.

Dunn, J. T. (200I). “Endemic goiter and cretinism: an update on iodine status.” Review.

J Pediatr Endocrinol Metab I4 Suppl 6: 1469-1473.

Dunn, J. T. (2003). "lodine should be routinely added to complementary

foods." J Nutr I33(9): 3008S-30I0S.

Dunn, J. T., et al. (200I). "Damaged reproduction: the most important consequence of iodine deficiency.” J Clin Endocrinol Metab 86(6): 2360-2363.

\section{Reason for exclusion}

Review.

Review.

Review.

Descriptive study about UIC at population level from several countries in Europe.

Current opinion. Review.

The objective is to describe status in Belgium. We have similar stories from the Nordic countries.

cancer patients, concluding that high intake is the main risk factor, but don't include food. Not relevant.

Methodological aspect, outside our research questions.

Cross sectional study, says nothing about iodine intake.

High intake not linked to any outcome in the paper, thyroid volume and UIC nothing about dietary intake.

About fortification of foods.

Commentary. 
Article

Dunn, J. T., et al. (200I). "Update on intrathyroidal iodine metabolism." Thyroid I I(5): 407-4I4.

Duntas, L. H. (2008). "Environmental factors and autoimmune thyroiditis." Nat Clin Pract Endocrinol Metab 4(8): 454460.

Elnour, A., et al. (2000). "Endemic goiter with iodine sufficiency: a possible role for the consumption of pearl millet in the etiology of endemic goiter." $A m$ J Clin Nutr 7 I (I): 59-66.

Eltom, A., et al. (2000). "Thyroglobulin in serum as an indicator of iodine status during pregnancy." Scand J Clin Lab Invest 60(I): I-7.

Eltom, A., et al. (2000). "Changes in iodine metabolism during late pregnancy and lactation: a longitudinal study among Sudanese women." Eur J Clin Nutr 54(5): 429-433.

Eltom, A., et al. (200I). "Thyroid function in the newborn in relation to maternal thyroid status during labour in a mild iodine deficiency endemic area in Sudan." Clin Endocrinol (Oxf) 55(4): 485-490.

Fadeyev, V., et al. (2003). "Prevalence of thyroid disorders in pregnant women with mild iodine deficiency." Gynecol Endocrinol I7(5): 4I3-4I8.

Farahati, J., et al. (2006). "Gender-specific determinants of goiter." Biol Trace Elem Res II3(3): 223-230.

Fields, C., et al. (2005). "lodine-deficient vegetarians: a hypothetical perchlorate-susceptible population?” Regul Toxicol Pharmacol 42(I): 37-46.

Galanti, M. R., et al. (2007). "Smoking and environmental iodine as risk factors for thyroiditis among parous women." Eur J Epidemiol 22(7): 467-472.

Gartner, R. (2009). "Thyroid diseases in pregnancy." Curr Opin Obstet Gynecol 2 I (6): 50I-507.

Gatseva, P. D., et al. (2005). "lodine status of children living in areas with high nitrate levels in water." Arch Environ Occup Health 60(6): 317-319.

Giray, B., et al. (200I). "Status of selenium and antioxidant enzymes of goitrous children is lower than healthy controls and nongoitrous children with high iodine deficiency." Biol Trace Elem Res 82(I-3): 35-52.

Girelli, M. E., et al. (2004). "Milk represents an important source of iodine in schoolchildren of the Veneto region, Italy." J Endocrinol Invest 27(8): 709-7|3.

Glinoer, D. (200I). "Pregnancy and iodine." Thyroid I I (5): 47I-48I

Glinoer, D. (2003). "Feto-maternal repercussions of iodine deficiency during Review.

pregnancy. An update." Ann Endocrinol (Paris) 64(I): 37-44.

Glinoer, D. (2004). "The regulation of thyroid function during normal pregnancy: importance of the iodine nutrition status." Best Pract Res Clin Endocrinol Metab 18(2): 133-152.

Glinoer, D. (2006). "lodine nutrition requirements during pregnancy." Thyroid Guest editorial.

16(10): 947-948.

Glinoer, D. (2007). "Clinical and biological consequences of iodine deficiency Review. during pregnancy." Endocr Dev 10: 62-85.

Glinoer, D. (2007). "The importance of iodine nutrition during pregnancy." Public Health Nutr 10(12A): 1542-1546.

Glinoer, D., et al. (2009). "Gestational hypothyroxinemia and the beneficial effects of early dietary iodine fortification." Thyroid 19(5): 43I-434.

Golkowski, F., et al. (2007). "Increased prevalence of hyperthyroidism as an early and transient side-effect of implementing iodine prophylaxis." Public Health Nutr 10(8): 799-802.

Grantham-McGregor, S. M., et al. (2000). "Nutritional deficiencies and later Review. behavioural development." Proc Nutr Soc 59(I): 47-54.

\section{Reason for exclusion}

Review.

Review.

Not relevant, Sudan, pearl millet, very iodine-deficient people.

Methodological paper assessing status in the mother (Sudan and Swedish), no food or supplement use described in the paper, not relevant to research questions.

Sudan, describing status in the mother, no food or supplement use described in the paper.

Not relevant to the research questions.

Prevalence/cross-sectional, not Nordic and does not make any exact conclusion, none outcome in the infant.

Only descriptive, nothing about iodine intake.

Not relevant to the research question. Perclorate. Review of US vegetarian.

Smoking, risk of overt thyroiditis, nothing about iodine intake.

Review.

Not relevant to our research questions - cross sectional study about nitrate intake in children in Bulgaria.

Not relevant for our research questions, cross sectional study from Turkey.

Descriptive, importance of milk in childhood in Italy.

Review

Review.

Guest editorial.

From Poland. Descriptive about hyperthyroidism. Similar effects reported from Denmark. 
Appendix 2 (Continued)

Article

Reason for exclusion

Gregory, C. O., et al. (2009). "Use of supplements with and without iodine in Comment to editor. women of childbearing age in the United States." Thyroid 19(9): 1019-1020.

Guan, H., et al. (2008). "Influence of iodine on the reference interval of TSH The aim is to determine a reference interval for TSH in a Chinese and the optimal interval of TSH: results of a follow-up study in areas with population.

different iodine intakes." Clin Endocrinol (Oxf) 69(I): I36-I4I.

Gunnarsdottir, I., et al. (2009). "lodine intake and status in Iceland through a Review

period of 60 years." Food \& Nutrition Research 53 (27 May): I-4.

Guo, T. W., et al. (2005). "Polymorphisms in the TSHR (thyrotropin receptor) Not related to the research questions

gene on chromosome $|4 q 3|$ are not associated with mental retardation in the

iodine-deficient areas of China." Neurosci Lett 382(I-2): 179-184.

Guo, T. W., et al. (2004). "Positive association of the DIO2 (deiodinase type 2) Not related to the research questions gene with mental retardation in the iodine-deficient areas of China." J Med

Genet 4 I (8): 585-590.

Hashemipour, M., et al. (2008). "Goiter persistence after iodine replenish- Cross sectional inconclusive from Iran.

ment, the potential role of selenium deficiency in goitrous schoolchildren of

Semirom, Iran." Exp Clin Endocrinol Diabetes I I6(2): 75-79.

Hays, M. T. (200I). "Estimation of total body iodine content in normal young Include only 6 subjects.

men." Thyroid I I(7): 67I-675.

Hess, S. Y. (2010). "The impact of common micronutrient deficiencies on Review.

iodine and thyroid metabolism: the evidence from human studies." Best Pract

Res Clin Endocrinol Metab 24(I): II7-I32.

Hess, S. Y., et al. (2004). "The effect of micronutrient deficiencies on iodine Review. nutrition and thyroid metabolism." Int J Vitam Nutr Res 74(2): 103-II5.

Hess, S. Y., et al. (200I). "Monitoring the adequacy of salt iodization in

Only status, salt iodine increased on the population level, no Switzerland: a national study of school children and pregnant women." Eur J information on individual intake.

Clin Nutr 55(3): 162-166.

Hetzel, B. S. (2000). "lodine and neuropsychological development." J Nutr From a symposium on trace element and human health.

I30(2S Suppl): 493S-495S.

Hollowell, J. G., et al. (2002). "Serum TSH, T(4), and thyroid antibodies in the Thyroid levels in US population.

United States population (1988 to 1994): National Health and Nutrition

Examination Survey (NHANES III)." J Clin Endocrinol Metab 87(2): 489-499.

Hoogendoorn, E. H., et al. (2006). "Thyroid function and prevalence of anti- Not relevant to iodine intake (lack of information) thyroid function,

thyroperoxidase antibodies in a population with borderline sufficient iodine prevalence.

intake: influences of age and sex." Clin Chem 52(I): 104-III.

Hoption Cann, S. A. (2006). "Hypothesis: dietary iodine intake in the etiology Review.

of cardiovascular disease." J Am Coll Nutr 25(I): I-II.

Horton, S. (2006). "The economics of food fortification." J Nutr 136(4): Symposium. Review.

1068-107|.

Huszno, B., et al. (2003). "Influence of iodine deficiency and iodine prophylaxis Inconclusive, about thyroid cancer and radiation, intake based on on thyroid cancer histotypes and incidence in endemic goiter area." J

Endocrinol Invest 26(2 Suppl): 71-76.

Ibrahim, M., et al. (2006). "lodine supplementation for the prevention of mortality and adverse neurodevelopmental outcomes in preterm infants."

Cochrane Database Syst Rev(2): CD005253.

Kabelitz, M., et al. (2003). "The prevalence of anti-thyroid peroxidase Cross sectional study.

antibodies and autoimmune thyroiditis in children and adolescents in an iodine

replete area." Eur J Endocrinol I48(3): 30I-307.

Kaloumenou, I., et al. (2007). "Thyroid volume and echostructure in

Descriptive, cross-sectional study, not including any specific endpoint schoolchildren living in an iodine-replete area: relation to age, pubertal stage, except function of the thyroid.

and body mass index." Thyroid 17(9): 875-88I. 
Kaloumenou, l., et al. (2008). "Thyroid autoimmunity in schoolchildren in an Cross sectional study area with long-standing iodine sufficiency: correlation with gender, pubertal stage, and maternal thyroid autoimmunity." Thyroid 18(7): 747-754. Karmisholt, J., et al. (2008). "Serum TSH and serum thyroid peroxidase antibody fluctuate in parallel and high urinary iodine excretion predicts subsequent thyroid failure in a I-year study of patients with untreated subclinical hypothyroidism." Eur J Endocrinol I58(2): 209-2I5.

Knobel, M., et al. (2007). "Relevance of iodine intake as a reputed

Descriptive study, include 2 I sublinical hypothyroidism subjects

Review. predisposing factor for thyroid cancer." Arq Bras Endocrinol Metabol 5 I (5): $70|-7| 2$.

Knudsen, N., et al. (200I). "Serum Tg-a sensitive marker of thyroid abnormalities and iodine deficiency in epidemiological studies." J Clin Endocrinol Metab 86(8): 3599-3603.

Knudsen, N., et al. (2003). "Low socio-economic status and familial occurrence of goitre are associated with a high prevalence of goitre." Eur J Epidemiol 18(2): 175-181.

Knudsen, N., et al. (200I). "Alcohol consumption is associated with reduced prevalence of goitre and solitary thyroid nodules." Clin Endocrinol (Oxf) 55(I): 4I-46.

Knudsen, N., et al. (2002). "High occurrence of thyroid multinodularity and low occurrence of subclinical hypothyroidism among tobacco smokers in a large population study." J Endocrinol 175(3): 57I-576.

Knudsen, N., et al. (2002). "Low goitre prevalence among users of oral contraceptives in a population sample of 3712 women." Clin Endocrinol (Oxf) 57(I): 7I-76.

Knudsen, N., et al. (2006). "lodine and metabolic diseases. Consequences of Overview.

iodine deficiency." Månedsskrift for praktisk laegegerning 84(I2): |3|7-|323.

Knudsen, N., et al. (2002). "Parity is associated with increased thyroid volume Not related to the research question.

solely among smokers in an area with moderate to mild iodine deficiency." Eur

J Endocrinol 146(I): 39-43.

Kunachowicz, H., et al. (2002). "Studies on iodine content in daily diets, particularly elderly people's diets." J Nutr Health Aging 6(2): I27-129.

Kung, A. W., et al. (2000). "Goitrogenesis during pregnancy and neonatal hypothyroxinaemia in a borderline iodine sufficient area." Clin Endocrinol (Oxf) 53(6): 725-73I.

Langer, P., et al. (2007). "Fish from industrially polluted freshwater as the main Not relevant. source of organochlorinated pollutants and increased frequency of thyroid disorders and dysglycemia." Chemosphere 67(9): S379-385.

Langer, P., et al. (2007). "Thyroid ultrasound volume, structure and function after long-term high exposure of large population to polychlorinated biphenyls, pesticides and dioxin." Chemosphere 69(I): II8-127.

Lamberg, B. A. (2003). "[lodine deficiency exists in many European countries but not in Finland]." Duodecim I19(17): 1639-1642.

Langer, P., et al. (2003). "Multimodal distribution versus logarithmic transformation of thyroid volumes in adolescents: detection of subgroup with subclinical thyroid disorders and its impact on the assessment of the upper limit of normal thyroid volumes." Endocr J 50(2): 117-125.

Laurberg, P. (2005). "Global or Gaelic epidemic of hypothyroidism?" Lancet 365(946I): 738-740.

Laurberg, P. (2009). "Thyroid function: Thyroid hormones, iodine and the brain-an important concern.” Nat Rev Endocrinol 5(9): 475-476.
Methodological paper, outside research question.

Descriptive study, socio-economic status and goitre.

Descriptive study about alcohol consumption and goitre. Thyroid volume as endpoint measure.

Smoking and thyroid function, includes nothing about iodine intake.

Descriptive study about goitre and use of oral contraceptives.

Descriptive from Poland, not relevant.

Not relevant.

Almost the same as Langer et al. 2007 about fish from industrially polluted freshwater.

Review

Methodological paper, outside research question.

Comment on paper.

Short overview. 
Appendix 2 (Continued)

Article

Reason for exclusion

Laurberg, P., et al. (2007). "Evaluating iodine deficiency in pregnant women Review methods for assessing iodine status. and young infants-complex physiology with a risk of misinterpretation." Public Health Nutr I0(12A): 1547-1552; discussion 1553.

Laurberg, P., et al. (2002). "Thiocyanate in food and iodine in milk: from Review.

domestic animal feeding to improved understanding of cretinism." Thyroid

I2(I0): 897-902.

Laurberg, P., et al. (200I). "Environmental iodine intake affects the type of Review.

nonmalignant thyroid disease." Thyroid I I (5): 457-469.

Laurberg, P., et al. (2010). "lodine intake as a determinant of thyroid disorders Review, however included in the SLR as it is from the Nordic countries. in populations." Best Pract Res Clin Endocrinol Metab 24(I): 13-27.

Laurberg, P., et al. (2006). "The Danish investigation on iodine intake and Review.

thyroid disease, DanThyr: status and perspectives." Eur J Endocrinol I55(2):

219-228.

Laurberg, P., et al. (2000). "Thyroid disorders in mild iodine deficiency." Review.

Thyroid I0(II): 95I-963.

Lazarus, J. H., et al. (2004). "Prevalence of iodine deficiency worldwide." Correspondence.

Lancet 363(9412): 901 .

Li, M., et al. (2010). "Neonatal TSH screening: is it a sensitive and reliable tool Methodological paper about neonatal TSH screening, outside research for monitoring iodine status in populations?" Best Pract Res Clin Endocrinol question.

Metab 24(I): 63-75.

$\mathrm{Li}$, Y., et al. (2008). "Antithyroperoxidase and antithyroglobulin antibodies in a From China, cross sectional study, about thyroid function.

five-year follow-up survey of populations with different iodine intakes." J Clin

Endocrinol Metab 93(5): 175I-1757.

Mahomed, K., et al. (2000). "WITHDRAWN: Maternal iodine supplements in Withdrawn.

areas of deficiency." Cochrane Database Syst Rev(2): CD000I 35.

Mahomed, K., et al. (2006). "WITHDRAWN: Maternal iodine supplements in Withdrawn.

areas of deficiency." Cochrane Database Syst Rev(3): CD000I35.

Manz, F., et al. (2000). "lodine supply in children from different european

areas: the Euro-growth study. Committee for the Study of lodine Supply in

Cross sectional study with UIC as endpoint.

European Children." J Pediatr Gastroenterol Nutr 3 I Suppl I: S72-75.

Mason, J. B., et al. (2002). "Iodine fortification is related to increased weight- Inconclusive results (cross-sectional mainly) and not related to Nordic

for-age and birthweight in children in Asia." Food Nutr Bull 23(3): 292-308. nutrition (conducted in Asia).

Melse-Boonstra, A., et al. (2010). "lodine deficiency in pregnancy, infancy and Review.

childhood and its consequences for brain development." Best Pract Res Clin

Endocrinol Metab 24(I): 29-38.

Mian, C., et al. (2009). "lodine status in pregnancy: role of dietary habits and Review.

geographical origin." Clin Endocrinol (Oxf) 70(5): 776-780.

Milakovic, M., et al. (2006). "Effect of lifelong iodine supplementation on Descriptive study, I3I-I uptake as endpoint.

thyroid I3I-I uptake: a decrease in uptake in euthyroid but not hyperthyroid

individuals compared to observations 50 years ago." Eur J Clin Nutr 60(2):

210-213.

Milerova, J., et al. (2006). "Actual levels of soy phytoestrogens in children

correlate with thyroid laboratory parameters." Clin Chem Lab Med 44(2):

Not relevant to the research questions.

|7|-174.

Mirmiran, P., et al. (2002). "Three-year survey of effects of iodized oil injection Not relevant for the Nordic countries, covered by the Cohrane review. in schoolchildren with iodine deficiency disorders." Exp Clin Endocrinol

Diabetes I I0(8): 393-397.

Mithen, R. (2007). "Effect of genotype on micronutrient absorption and Review.

metabolism: a review of iron, copper, iodine and selenium, and folates." Int J

Vitam Nutr Res 77(3): 205-216.

Morreale de Escobar, G., et al. (2004). "Role of thyroid hormone during early Review

brain development.” Eur J Endocrinol I5 I Suppl 3: U25-37. 
Mukhopadhyay, S., et al. (2005). "Evaluation of possible goitrogenic and anti- Animal study about nitrate exposure. thyroidal effect of nitrate, a potential environmental pollutant." Indian J Physiol Pharmacol 49(3): 284-288.

Nishiyama, S., et al. (2004). "Transient hypothyroidism or persistent

lodine excess intake from seaweed as kombu. hyperthyrotropinemia in neonates born to mothers with excessive iodine intake." Thyroid 14(12): 1077-1083.

Oberlin, O., et al. (2006). "Goitre and iodine deficiency in Afghanistan: a casecontrol study." Br J Nutr 95(I): 196-203.

Obregon, M. J., et al. (2005). "The effects of iodine deficiency on thyroid hormone deiodination." Thyroid I 5(8): 917-929.

Ohara, N., et al. (2004). "The role of thyroid hormone in trophoblast function, early pregnancy maintenance, and fetal neurodevelopment." J Obstet Gynaecol Can 26(II): 982-990.

Ovesen, L., et al. (2002). "The use of biomarkers in multicentric studies with particular consideration of iodine, sodium, iron, folate and vitamin D." Eur J

Clin Nutr 56 Suppl 2: S12-17.

Papanastasiou, L., et al. (2007). "Thyroid autoimmunity in the current iodine Review.

environment." Thyroid I7(8): 729-739.

Prakash, R. (2005). "High thyroid volume in children with excess dietary

Letter to the editor

iodine intakes.” Am J Clin Nutr 82(3): 708-709.

Patrick, L. (2008). "lodine: deficiency and therapeutic considerations." Altern Review.

Med Rev 13(2): 116-127.

Pearce, E. N. (2009). "What do we know about iodine supplementation in pregnancy?" J Clin Endocrinol Metab 94(9): 3188-3190.

Pearce, E. N., et al. (2002). "Effects of chronic iodine excess in a cohort of High intake due to high content of iodine in drinking water. long-term American workers in West Africa." J Clin Endocrinol Metab 87( (2): 5499-5502.

Pearce, E. N., et al. (2007). "Breast milk iodine and perchlorate concentrations Not relevant. in lactating Boston-area women." J Clin Endocrinol Metab 92(5): 1673-1677.

Pedersen, I. B., et al. (2007). "An increased incidence of overt hypothyroidism Cases of overt hypothyroidism in two areas in DK, salt fortification and after iodine fortification of salt in Denmark: a prospective population study." J cases of hypothyroidism.

Clin Endocrinol Metab 92(8): 3122-3127.

Pemberton, H. N., et al. (2005). "Thyroid hormones and fetal brain Review.

development.” Minerva Ginecol 57(4): 367-378.

Perez-Lopez, F. R. (2007). "lodine and thyroid hormones during pregnancy and Review.

postpartum." Gynecol Endocrinol 23(7): 414428.

Pizzulli, A., et al. (2000). "Selenium deficiency and hypothyroidism: a new

etiology in the differential diagnosis of hypothyroidism in children." Biol Trace

Elem Res 77(3): 199-208.

Qian, M., et al. (2005). "The effects of iodine on intelligence in children: a meta-analysis of studies conducted in China." Asia Pac J Clin Nutr 14(I): 32

42.

Radetti, G., et al. (2002). "Foetal and neonatal thyroid disorders." Minerva Review.

Pediatr 54(5): 383-400.

Rasmussen, L. B., et al. (2002). "Relations between various measures of iodine Met intake and thyroid volume, thyroid nodularity, and serum thyroglobulin." Am J

Clin Nutr 76(5): 1069-1076.

Rayburn, W. F., et al. (2008). "lodide concentrations in matched maternal serum, cord serum, and amniotic fluid from preterm and term human

pregnancies." Reprod Toxicol 25(I): I29-132.

Case report.

Limited to studies from China, not relevant in the Nordic setting.

Methodological issues. Not related to the research question.

Short communication, lack of information, only iodine status of the mother, no endpoint in the fetus/infant. 
Appendix 2 (Continued)

Article

Raymond, J., et al. (20I0). "Fetal and neonatal thyroid function: review and summary of significant new findings." Curr Opin Endocrinol Diabetes Obes I 7(I): I-7.

Rebagliato, M., et al. (2010). "lodine intake and maternal thyroid function during pregnancy.” Epidemiology 21 (I): 62-69.

Remer, T., et al. (2006). "Longitudinal examination of 24-h urinary iodine excretion in schoolchildren as a sensitive, hydration status-independent research tool for studying iodine status.” Am J Clin Nutr 83(3): 639-646.

Restani, P., et al. (2008). "Analysis of food supplements containing iodine: a survey of Italian market.” Clin Toxicol (Phila) 46(4): 282-286.

Ristic-Medic, D., et al. (2009). "Methods of assessment of iodine status in humans: a systematic review." Am J Clin Nutr 89(6): 2052S-2069S.

Robbins, J., et al. (200I). "lodine nutrition and the risk from radioactive iodine: a workshop report in the Chernobyl long-term follow-up study." Thyroid

I I(5): 487-49 I.

Rogahn, J., et al. (2000). "Randomised trial of iodine intake and thyroid status in preterm infants." Arch Dis Child Fetal Neonatal Ed 83(2): F86-90.

Rotondi, M., et al. (2000). "Parity as a thyroid size-determining factor in areas with moderate iodine deficiency." J Clin Endocrinol Metab 85(I 2): 45344537.

Sack, J. (2003). "Thyroid function in pregnancy-maternal-fetal relationship in Review.

health and disease." Pediatr Endocrinol Rev I Suppl 2: I70-176; discussion 176.

Savin, S., et al. (2003). "Thyroid hormone synthesis and storage in the thyroid gland of human neonates.” J Pediatr Endocrinol Metab I 6(4): 52I-528.

Serreau, R., et al. (2004). "Fetal thyroid goiter after massive iodine exposure." Prenat Diagn 24(9): 75I-753.

Sethi, V., et al. (2004). "lodine deficiency and development of brain." Indian J Review.

Pediatr 7I(4): 325-329.

Siklar, Z., et al. (2002). "Borderline congenital hypothyroidism in the neonatal period." J Pediatr Endocrinol Metab I5(6): 8I7-82I.

Smyth, P. P. (2003). "The thyroid, iodine and breast cancer.” Breast Cancer Res 5(5): 235-238.

Smyth, P. P., et al. (2007). "Short-term changes in maternal and neonatal urinary iodine excretion." Thyroid I7(3): 219-222.

Soldin, O. P., et al. (2003). "Urinary iodine percentile ranges in the United States." Clin Chim Acta 328(I-2): 185-190.

Soldin, O. P., et al. (2004). "Trimester-specific changes in maternal thyroid hormone, thyrotropin, and thyroglobulin concentrations during gestation: trends and associations across trimesters in iodine sufficiency." Thyroid I4(12): 1084-1090.

Soldin, O. P., et al. (2005). "Do thyroxine and thyroid-stimulating hormone levels reflect urinary iodine concentrations?” Ther Drug Monit 27(2): I78185.

Soriguer, F., et al. (2009). "Clinical dilemmas arising from the increased intake of iodine in the Spanish population and the recommendation for systematic prescription of potassium iodide in pregnant and lactating women (Consensus of the TDY Working Group of SEEN).” J Endocrinol Invest 32(2): I84-191. Steinmaus, C., et al. (2007). "Impact of smoking and thiocyanate on perchlorate and thyroid hormone associations in the 2001-2002 national health and nutrition examination survey." Environ Health Perspect I I5(9): |333-1338.
Review.

Review

Longitudinal descriptive study about the $24 \mathrm{~h}$ urinary iodine excretion in German children.

Supplement analysis of iodine in Italy.

Methodological paper, outside research question.

Workshop report. Review.

Preterm infants, not related to the research question (trial where diff amounts of iodine is given in preterm formula).

Not related to nutrition.

No information on iodine intake or status. Very preterm infants and preterm infants (not healthy and died in the first month).

Letter and a case report (short).

Descriptive and not relevant to Nordic diet, children with jaundice.

Commentary about breast cancer and thyroid disease.

Not related to nutrition, small sample and short time.

UIC values from US

Not relevant to the research question, only describing the changes in hormones in the pregnant mother.

Methodological aspect, outside our research questions.

Overview.

Not relevant to nutrition, mainly perchlorate. 
Sullivan, K. M. (2007). "lodine supplementation for pregnancy and lactation: Letter to the editor. United States and Canada: recommendations of the American Thyroid Association.” Thyroid 17(5): 483-484.

Takats, I. K., et al. (2000). "The blood spot thyrotropin method is not Methodological aspect, outside our research questions. adequate to screen for hypothyroidism in the elderly living in abundant-iodine intake areas: comparison to sensitive thyrotropin measurements." Thyroid I0(I): 79-85.

Teas, J., et al. (2007). "Seaweed and soy: companion foods in Asian cuisine and Few participant, semi relevant to research questions, about soy and their effects on thyroid function in American women." J Med Food I 0(I): 90- seaweed.

100

Teng, W., et al. (2006). "Effect of iodine intake on thyroid diseases in China." N From China, iodine supplementation and thyroid disease, does not Engl J Med 354(26): 2783-2793. include dietary intake data.

Teng, X., et al. (2008). "Safe range of iodine intake levels: a comparative study Methodological aspect, outside our research questions. of thyroid diseases in three women population cohorts with slightly different iodine intake levels." Biol Trace Elem Res I2I(I): 23-30.

Thomas Jde, V., et al. (2009). "Perinatal goiter with increased iodine uptake Case report, include 8 cases from Brazil. and hypothyroidism due to excess maternal iodine ingestion." Horm Res 72(6): 344-347.

Thomson, C. D., et al. (2009). "Selenium and iodine supplementation: effect From New Zeeland. on thyroid function of older New Zealanders." Am J Clin Nutr 90(4): 1038

1046.

Triggiani, V., et al. (2004). "Prospective study of post-partum thyroid immune Women diabetic, small number of subjects $(n=28)$.

dysfunctions in type I diabetic women and in a healthy control group living in a mild iodine deficient area." Immunopharmacol Immunotoxicol 26(2): 215-

224.

Untoro, J., et al. (2007). "Reaching optimal iodine nutrition in pregnant and lactating women and young children: programmatic recommendations." Public Health Nutr 10(12A): 1527-1529.

Untoro, J., et al. (2010). "The challenges of iodine supplementation: a public Review. health programme perspective.” Best Pract Res Clin Endocrinol Metab 24(I): 89-99.

Valentino, R., et al. (2004). "Screening a coastal population in Southern Italy: iodine deficiency and prevalence of goitre, nutritional aspects and cardiovascular risk factors." Nutr Metab Cardiovasc Dis 14(I): 15-19.

Van Der Haar, F. (2007). "Goiter and other iodine deficiency disorders: a systematic review of epidemiological studies to deconstruct the complex web." Arch Med Res 38(5): 586-587; author reply 588-589.

Vanderver, G. B., et al. (2007). "Cigarette smoking and iodine as

Editorial.

hypothyroxinemic stressors in U.S. women of childbearing age: a NHANES III analysis." Thyroid I7(8): 74I-746.

Wang, H. Y., et al. (2000). "Apolipoprotein E is a genetic risk factor for fetal From China, outside research questions. iodine deficiency disorder in China." Mol Psychiatry 5(4): 363-368.

Vejbjerg, P., et al. (2009). "Estimation of iodine intake from various urinary iodine measurements in population studies." Thyroid I9(II): I28I-I286.

Vejbjerg, P., et al. (2009). "Thyroglobulin as a marker of iodine nutrition status Methodological paper, outside research question. in the general population." Eur J Endocrinol 161(3): 475-48I.

Venturi, S., et al. (2000). "Role of iodine in evolution and carcinogenesis of Review. thyroid, breast and stomach." Adv Clin Path 4(I): II-17.

Venturi, S., et al. (2009). "lodine in evolution of salivary glands and in oral health." Nutr Health 20(2): I19-134.

Letter to the editor.

From USA, smoking and hypothyroxinemic.

Methodological paper, outside research question.

Methodological aspect, outside our research questions. 
Appendix 2 (Continued)

Article

Verger, P., et al. (200I). "lodine kinetics and effectiveness of stable iodine prophylaxis after intake of radioactive iodine: a review." Thyroid I I (4):

353-360.

Verheesen, R. H., et al. (2008). "lodine deficiency, more than cretinism and Review.

goiter." Med Hypotheses 7I(5): 645-648.

Vermiglio, F., et al. (2004). "Attention deficit and hyperactivity disorders in the offspring of mothers exposed to mild-moderate iodine deficiency: a possible novel iodine deficiency disorder in developed countries." J Clin Endocrinol

Metab 89(12): 60546060.

Vestergaard, P., et al. (2002). "Smoking as a risk factor for Graves' disease, toxic nodular goiter, and autoimmune hypothyroidism." Thyroid I 2(I): 69-75.

Williams, G. R. (2008). "Neurodevelopmental and neurophysiological actions Review.

of thyroid hormone." J Neuroendocrinol 20(6): 784-794.

Vitti, P., et al. (200I). "lodine deficiency disorders in Europe." Public Health Review

Nutr 4(2B): 529-535.

Wu, T., et al. (2002). "lodised salt for preventing iodine deficiency disorders." Review.

Cochrane Database Syst Rev(3): CD003204.

Zagrodzki, P., et al. (2000). "The role of selenium in iodine metabolism in

children with goiter." Environ Health Perspect 108(I): 67-7I.

from Poland.

Zeisel, S. H. (2009). "Is maternal diet supplementation beneficial? Optimal development of infant depends on mother's diet." Am J Clin Nutr 89(2):

$685 S$ - $687 \mathrm{~S}$.

Zhao, J., et al. (2000). "Endemic goiter associated with high iodine intake.” $A m$ J Public Health 90(10): 1633-1635.

Zimmermann, M., et al. (2000). "Low dose oral iodized oil for control of iodine deficiency in children." Br J Nutr 84(2): |39-|4|.

Zimmermann, M., et al. (2004). "lodine supplementation of pregnant women in Europe: a review and recommendations.” Eur J Clin Nutr 58(7): 979-984.

Zimmermann, M. B. (2002). "Iron status influences the efficacy of iodine prophylaxis in goitrous children in Cote d'Ivoire." Int J Vitam Nutr Res 72(I): 19-25.

Zimmermann, M. B. (2004). "Assessing iodine status and monitoring progress of iodized salt programs." J Nutr 134(7): 1673-1677.

Zimmermann, M. B. (2007). "The adverse effects of mild-to-moderate iodine Review. deficiency during pregnancy and childhood: a review." Thyroid I 7(9): 829-835. Zimmermann, M. B. (2007). "The impact of iodised salt or iodine supplements Review. on iodine status during pregnancy, lactation and infancy." Public Health Nutr I0(I2A): I584-I595.

Zimmermann, M. B. (2008). "lodine requirements and the risks and benefits of Review. correcting iodine deficiency in populations." J Trace Elem Med Biol 22(2): 8I-

92.

Zimmermann, M. B. (2009). “lodine deficiency.” Endocr Rev 30(4): 376-408. Review.

Zimmermann, M. B. (2009). "lodine deficiency in pregnancy and the effects of Review. maternal iodine supplementation on the offspring: a review." Am J Clin Nutr 89(2): 668S $672 \mathrm{~S}$.

Zimmermann, M. B. (2010). "Symposium on 'Geographical and geological influences on nutrition': lodine deficiency in industrialised countries." Proc Nutr Soc 69(I): 133-143.

Zimmermann, M. B., et al. (2000). "Effect of oral iodized oil on thyroid size and thyroid hormone metabolism in children with concurrent selenium and iodine deficiency." Eur J Clin Nutr 54(3): 209-2I3.

Review.

Review.

\section{Reason for exclusion}

Cross sectional study

Do not assess any health effects of high intake of iodine due to high levels in water.

Intervention among very IDD children from Cote d'Ivoire - not relevant to the Nordic countries.

Interventions focusing on improvement of IDD in areas of endemic goiter in children are not relevant to the Nordic setting. We don't have as severe problems.

Methodological aspect, outside our research questions. 
Appendix 2 (Continued)

Article

Reason for exclusion

Zimmermann, M. B., et al. (2006). "Assessment of iodine status using dried blood spot thyroglobulin: development of reference material and establishment of an international reference range in iodine-sufficient children." J Clin Endocrinol Metab 9I (I2): 488I-4887.

Zimmermann, M. B., et al. (2008). "lodine-deficiency disorders." Lancet 372(9645): |25I-|262.

Zimmermann, M. B., et al. (2002). "The impact of iron and selenium

Seminar and review.

deficiencies on iodine and thyroid metabolism: biochemistry and relevance to public health." Thyroid I 2(10): 867-878.

Zimmermann, M. B., et al. (200I). "Toward a consensus on reference values for thyroid volume in iodine-replete schoolchildren: results of a workshop on inter-observer and inter-equipment variation in sonographic measurement of thyroid volume." Eur J Endocrinol I44(3): 213-220.

Zimmermann, M. B., et al. (2003). "Introduction of iodized salt to severely iodine-deficient children does not provoke thyroid autoimmunity: a I-year prospective trial in northern Morocco." Thyroid I3(2): 199-203.

Zimmermann, M. B., et al. (2004). "Rapid relapse of thyroid dysfunction and goiter in school-age children after discontinuation of salt iodization." Am J Clin Nutr 79(4): 642-645.

Zimmermann, M. B., et al. (2002). "Addition of microencapsulated iron to iodized salt improves the efficacy of iodine in goitrous, iron-deficient children: a randomized, double-blind, controlled trial." Eur J Endocrinol I47(6): 747-

753.

Zois, C., et al. (2003). "High prevalence of autoimmune thyroiditis in Supplementation in very IDD area. Not related to NNR schoolchildren after elimination of iodine deficiency in northwestern Greece."

Thyroid 13(5): 485-489. 
Appendix 3. (studies presented in summary table 1). Iodine status and iodine supplementation in pregnancy; pregnancy outcome and thyroid function in the mother and offspring.

\begin{tabular}{|c|c|c|c|c|c|c|c|c|c|c|c|c|}
\hline $\begin{array}{l}\text { Reference, } \\
\text { details, first } \\
\text { author year, } \\
\text { country }\end{array}$ & $\begin{array}{l}\text { Study } \\
\text { design }\end{array}$ & $\begin{array}{l}\text { Population, } \\
\text { subject }\end{array}$ & $\begin{array}{l}\text { Outcome } \\
\text { measures }\end{array}$ & $\begin{array}{l}\text { Intervention/ } \\
\text { exposure }\end{array}$ & $\begin{array}{l}\text { Time between } \\
\text { baseline exposure } \\
\text { and outcome } \\
\text { assessment }\end{array}$ & $\begin{array}{l}\text { Dietary } \\
\text { assessment } \\
\text { method }\end{array}$ & $\begin{array}{l}\text { No. of } \\
\text { subjects } \\
\text { analyzed }\end{array}$ & Intervention & $\begin{array}{l}\text { Follow-up } \\
\text { period, } \\
\text { drop-out } \\
\text { rate }\end{array}$ & Results & $\begin{array}{l}\text { Confounders } \\
\text { adjusted for }\end{array}$ & $\begin{array}{l}\text { Study quality and } \\
\text { relevance, } \\
\text { Comments } \\
\text { A-C }\end{array}$ \\
\hline $\begin{array}{l}\text { Antonangeli } \\
\text { et al., 2002, } \\
\text { Italy (7) }\end{array}$ & $\begin{array}{l}\text { Clinical } \\
\text { trial }\end{array}$ & $\begin{array}{l}\text { pregnant women } \\
\text { ( } n=86 \text { ), 20-38 } \\
\text { years, enrolled } \\
\text { from I0th to the } \\
\text { I6th week } \\
\text { of gestation. } \\
\text { Women with } \\
\text { clinical and } \\
\text { laboratory } \\
\text { evidence of } \\
\text { hyperthyroidism, } \\
\text { hypothyroidism, } \\
\text { thyroid } \\
\text { autoimmunity } \\
\text { (thyroid } \\
\text { autoantibodies }> \\
\text { I:400) or thyroid } \\
\text { volume greater } \\
\text { than } \\
20 \text { mL were } \\
\text { excluded. After } \\
\text { recruitment } \\
7 \text { women } \\
\text { withdrew their } \\
\text { consent and I2 } \\
\text { dropped out of } \\
\text { the study (eight } \\
\text { because of } \\
\text { serious gestational } \\
\text { events). After } \\
\text { randomization the } \\
\text { UIE was } 91 \text { mcg/g } \\
\text { creatinine in } \\
\text { group A and } 65.5 \\
\text { mcg/g creatinine } \\
\text { in group B. }\end{array}$ & $\begin{array}{l}\text { UIE (casual } \\
\text { urinary } \\
\text { samples), } \\
\text { TV, FT4, } \\
\text { FT3, TSH, } \\
\text { Tg. }\end{array}$ & $\begin{array}{l}\text { Group A } \\
\text { received on } \\
\text { table iodide } \\
200 \text { per day } \\
\text { ( } 200 \mathrm{mcg} / \mathrm{d}) \\
\text { and group B } \\
\text { received I/2 } \\
\text { tablet iodide } \\
100 \text { ( } 50 \mathrm{mcg} / \\
\text { day). }\end{array}$ & $\begin{array}{l}\text { Subjects assessed at } \\
\text { 18th-26th week, } \\
\text { 29th-33rd week, 3rd } \\
\text { and 6th month after } \\
\text { delivery. }\end{array}$ & $\begin{array}{l}\text { No } \\
\text { assessment } \\
\text { of dietary } \\
\text { intake. }\end{array}$ & $\begin{array}{l}n=67 \\
(\mathrm{~A} n=32 \text { and } \\
\text { B } n=35) .\end{array}$ & $\begin{array}{l}200 \mathrm{mcg} \\
\text { iodine vs. } \\
50 \mathrm{mcg} \\
\text { iodine. }\end{array}$ & $\begin{array}{l}\text { Follow-up } \\
\text { period from } \\
\text { the first } \\
\text { trimester } \\
\text { throughout } \\
\text { pregnancy } \\
\text { to } 6 \text { months } \\
\text { after } \\
\text { delivery } \\
\text { (approx. I2- } \\
\text { I4 months). } \\
\text { Drop-out } \\
22.1 \% \text {. }\end{array}$ & $\begin{array}{l}\text { Six months } \\
\text { after } \\
\text { delivery UIC } \\
\text { was } 230 \mathrm{mg} / \\
\mathrm{g} \text { creatinine } \\
\text { in group A } \\
\text { and I } 28 \mathrm{mg} / \\
\mathrm{g} \text { creatinine } \\
\text { in group B. } \\
\text { No differ- } \\
\text { ence in TV, } \\
\text { Thyroid } \\
\text { function or } \\
\text { clinical } \\
\text { events found } \\
\text { between } \\
\text { groups. }\end{array}$ & 更 & $\begin{array}{l}\text { B No } \\
\text { information how } \\
\text { women were } \\
\text { randomized } \\
\text { into groups. } \\
\text { Observed } \\
\text { difference in } \\
\text { UIE after } \\
\text { randomization, } \\
\text { but no statistical } \\
\text { test presented if } \\
\text { this difference } \\
\text { is statistically } \\
\text { significant. } \\
\text { Neither } \\
\text { information on } \\
\text { lactation nor } \\
\text { iodine intake } \\
\text { from other } \\
\text { sources } \\
\text { reported. }\end{array}$ \\
\hline
\end{tabular}




\begin{tabular}{|c|c|c|c|c|c|c|c|c|c|c|c|c|}
\hline $\begin{array}{l}\text { Reference, } \\
\text { details, first } \\
\text { author year, } \\
\text { country }\end{array}$ & $\begin{array}{l}\text { Study } \\
\text { design }\end{array}$ & $\begin{array}{l}\text { Population, } \\
\text { subject }\end{array}$ & $\begin{array}{l}\text { Outcome } \\
\text { measures }\end{array}$ & $\begin{array}{l}\text { Intervention/ } \\
\text { exposure }\end{array}$ & $\begin{array}{l}\text { Time between } \\
\text { baseline exposure } \\
\text { and outcome } \\
\text { assessment }\end{array}$ & $\begin{array}{c}\text { Dietary } \\
\text { assessment } \\
\text { method }\end{array}$ & $\begin{array}{l}\text { No. of } \\
\text { subjects } \\
\text { analyzed }\end{array}$ & Intervention & $\begin{array}{l}\text { Follow-up } \\
\text { period, } \\
\text { drop-out } \\
\text { rate }\end{array}$ & Results & $\begin{array}{l}\text { Confounders } \\
\text { adjusted for }\end{array}$ & $\begin{array}{l}\text { Study quality and } \\
\text { relevance, } \\
\text { Comments } \\
\text { A-C }\end{array}$ \\
\hline $\begin{array}{l}\text { Nøhr \& } \\
\text { Laurberg, } \\
2000 \text {, } \\
\text { Denmark (9) }\end{array}$ & $\begin{array}{l}\text { Cohort } \\
\text { study }\end{array}$ & $\begin{array}{l}\text { Healthy pregnant } \\
\text { women with no } \\
\text { previous history } \\
\text { of thyroid disease, } \\
\text { from } 5 \text { different } \\
\text { regions of } \\
\text { Denmark } \\
\text { ( } n=\mid 52 \text { ). Women } \\
\text { with regular daily } \\
\text { intake of multivi- } \\
\text { tamin and mineral } \\
\text { tablet containing } \\
\text { iodine (I50 mcg) } \\
\text { during pregnancy } \\
\text { ( }+ \text { I group, } n=50 \text { ) } \\
\text { and women with } \\
\text { no artificial iodine } \\
\text { supplementation } \\
\text { (no I group, } \\
n=96) \text { continued } \\
\text { this study, } \\
\text { whereas women } \\
\text { who had a history } \\
\text { of intermittent } \\
\text { iodine supplemen- } \\
\text { tation ( } n=6 \text { ) } \\
\text { where excluded. } \\
\text { Median Ul in the } \\
+I \text { group was } 60 \\
\text { mcg/L and } 34.5 \\
\text { mcg/L in the no I } \\
\text { group. }\end{array}$ & $\begin{array}{l}\text { Maternal } \\
\text { and neona- } \\
\text { tal thyroid } \\
\text { function. UI } \\
\text { measured } \\
\text { in a spot } \\
\text { sample on } \\
\text { day } 5 \text { after } \\
\text { delivery. }\end{array}$ & $\begin{array}{l}\text { The } \\
\text { participants } \\
\text { were } \\
\text { instructed } \\
\text { to continue } \\
\text { their } \\
\text { previous } \\
\text { vitamin } \\
\text { and } \\
\text { mineral sup- } \\
\text { plementation } \\
\text { during the } \\
\text { puerperal } \\
\text { period. } \\
\text { I50mcg/day } \\
\text { or no } \\
\text { artificial } \\
\text { iodine. The } \\
\text { women } \\
\text { had been } \\
\text { recommen- } \\
\text { ded to take } \\
\text { vitamin and } \\
\text { mineral sup- } \\
\text { plementation } \\
\text { as part of } \\
\text { normal } \\
\text { pregnancy } \\
\text { care. }\end{array}$ & (1) & $\begin{array}{l}\text { Not } \\
\text { reported. }\end{array}$ & $\begin{array}{l}n=146 . \\
\text { Blood samples } \\
\text { from mothers } \\
\text { shortly after } \\
\text { admission for } \\
\text { labor } n=144 \text {, } \\
\text { mixed cord } \\
\text { blood samples } \\
n=139 \text {. }\end{array}$ & & & $\begin{array}{l}\text { Mothers in } \\
\text { the }+ \text { I } \\
\text { group had } \\
\text { lower TSH } \\
\text { (mU/L), } \\
\text { higher free } \\
\text { T4 (nmol/L) } \\
\text { and lower Tg } \\
\text { (mg/L) than } \\
\text { the no I } \\
\text { group } \\
\text { (median (25- } \\
75 \%) ; 2.06 \\
\text { (I.49-2.47) } \\
\text { vs. 2.23 } \\
\text { (I.65-3.08), } \\
8.4 \text { (7.5-9.7) } \\
\text { vs. } 7.9 \text { (7.0- } \\
8.8) \text { and I4.7 } \\
\text { (7.I-25.2) } \\
\text { vs. 25.8 } \\
\text { (I6.4-53.4), } \\
\text { respectively, } \\
P<0.05 . \text { The } \\
\text { neonates } \\
\text { showed a } \\
\text { pattern dif- } \\
\text { ferent from } \\
\text { the mothers. } \\
\text { The + I } \\
\text { group of } \\
\text { neonates } \\
\text { had higher }\end{array}$ & $\begin{array}{l}\text { Age, parity, } \\
\text { gestational } \\
\text { length or } \\
\text { birth weight } \\
\text { of the neo- } \\
\text { nates were } \\
\text { not different } \\
\text { between } \\
\text { groups. }\end{array}$ & $\begin{array}{l}\text { B The study } \\
\text { suggest that } \\
\text { iodine supple- } \\
\text { mentation of the } \\
\text { mother will, in } \\
\text { general, not } \\
\text { improve fetal } \\
\text { thyroid function } \\
\text { in areas such as } \\
\text { Denmark with } \\
\text { mild iodine defi- } \\
\text { ciency. A slightly } \\
\text { inhibitory effect } \\
\text { may be ex- } \\
\text { pected, which is } \\
\text { probably not of } \\
\text { clinical signifi- } \\
\text { cance. }\end{array}$ \\
\hline
\end{tabular}


Appendix 3 (Continued)

\begin{tabular}{|c|c|c|c|c|c|c|c|c|c|c|c|c|}
\hline $\begin{array}{l}\text { Reference, } \\
\text { details, first } \\
\text { author year, } \\
\text { country }\end{array}$ & $\begin{array}{l}\text { Study } \\
\text { design }\end{array}$ & $\begin{array}{l}\text { Population, } \\
\text { subject }\end{array}$ & $\begin{array}{l}\text { Outcome } \\
\text { measures }\end{array}$ & $\begin{array}{l}\text { Intervention/ } \\
\text { exposure }\end{array}$ & $\begin{array}{l}\text { Time between } \\
\text { baseline exposure } \\
\text { and outcome } \\
\text { assessment }\end{array}$ & $\begin{array}{l}\text { Dietary } \\
\text { assessment } \\
\text { method }\end{array}$ & $\begin{array}{l}\text { No. of } \\
\text { subjects } \\
\text { analyzed }\end{array}$ & Intervention & $\begin{array}{l}\text { Follow-up } \\
\text { period, } \\
\text { drop-out } \\
\text { rate }\end{array}$ & Results & $\begin{array}{l}\text { Confounders } \\
\text { adjusted for }\end{array}$ & $\begin{array}{l}\text { Study quality and } \\
\text { relevance, } \\
\text { Comments } \\
\text { A-C }\end{array}$ \\
\hline $\begin{array}{l}\text { Nøhr et al., } \\
2000, \\
\text { Denmark (8) }\end{array}$ & $\begin{array}{l}\mathrm{RCT} \text {, } \\
\text { double } \\
\text { blind } \\
\text { trial }\end{array}$ & $\begin{array}{l}\text { Women with } \\
\text { thyroid } \\
\text { peroxidase } \\
\text { antibodies } \\
\text { (TPO-Ab) } n=117 \\
\text { (prevalence } 9.1 \% \text { ) } \\
\text { from the healthy } \\
\text { pregnant Danish } \\
\text { women cohort } \\
\text { (age I8-35 years, } \\
n=\mid 284 \text { ), } \\
\text { screened at week } \\
\text { II (median). } \\
72 \text { TPO-Ab } \\
\text { women agreed to } \\
\text { participate (6I.5\% } \\
\text { of the eligible } \\
\text { population). }\end{array}$ & $\begin{array}{l}\text { Postpartum } \\
\text { thyroid } \\
\text { dysfunction } \\
\text { (PPTD) } \\
\text { defined as } \\
\text { abnormal } \\
\text { TSH in the } \\
\text { postpartum } \\
\text { period } \\
\text { (subclinical } \\
\text { hypothyr- } \\
\text { oidism if } \\
\text { only TSH } \\
\text { was abnor- } \\
\text { mal and } \\
\text { clinical hy- } \\
\text { pothyroid- } \\
\text { ism if TSH }\end{array}$ & $\begin{array}{l}\text { I50 mcg } \\
\text { iodine } \\
\text { supplement } \\
\text { or no iodine. } \\
\text { Group }+/+ \\
(n=22 / 22) \\
\text { pregnancy } \\
\text { and postpar- } \\
\text { tum, Group } \\
+/-(24 / 20 \\
\text { in pregnancy } \\
\text { only and } \\
\text { Group -/- } \\
\text { (26/24) re- } \\
\text { ceived no } \\
\text { supplements. }\end{array}$ & $\begin{array}{l}\text { Thyroid function } \\
\text { evaluated at II w, } 35 \\
\text { w, gestation and } 3,5 \text {, } \\
7 \text {, and } 9 \text { months } \\
\text { postpartum. }\end{array}$ & $\begin{array}{l}\text { Compliance } \\
\text { was evalu- } \\
\text { ated by 24-h } \\
\text { urinary } \\
\text { iodine mea- } \\
\text { surements at } \\
\text { time of } \\
\text { inclusion, } 35 \\
\text { w of preg- } \\
\text { nancy and } 7 \\
\text { months post- } \\
\text { partum. }\end{array}$ & $n=66$ & & $\begin{array}{l}\text { Follow-up } \\
\text { from gesta- } \\
\text { tional week } \\
\text { II through- } \\
\text { out preg- } \\
\text { nancy and to } \\
9 \text { months } \\
\text { postpartum. } \\
\text { Drop-out } \\
8 \% \text {. }\end{array}$ & $\begin{array}{l}\text { TSH than } \\
\text { the no I } \\
\text { group; } 9.00 \\
(6.18-|4.8|) \\
\text { vs. } 7.07 \\
(4.72-\mid \text { II.58), } \\
\text { while T4 was } \\
\text { higher and } \\
\text { Tg was low- } \\
\text { er in the } \\
\text { neonatal +I } \\
\text { group than } \\
\text { in the no I } \\
\text { group, simi- } \\
\text { lar to that in } \\
\text { the mothers. } \\
\text { No statistical } \\
\text { significant } \\
\text { difference in } \\
\text { the fre- } \\
\text { quency of } \\
\text { PPTD in the } \\
\text { three } \\
\text { groups, with } \\
\text { no } \\
\text { significant } \\
\text { increase } \\
\text { in the } \\
\text { prevalence, } \\
\text { severity, or } \\
\text { duration of } \\
\text { PPTD when } \\
\text { I50 mcg } \\
\text { iodine were }\end{array}$ & $\begin{array}{l}\text { Smoking, } \\
\text { group, age } \\
\text { and parity. }\end{array}$ & $\begin{array}{l}\text { A Unlikely that } \\
\text { supplementation } \\
\text { of } 150 \mathrm{mcg} / \text { day } \\
\text { will have adverse } \\
\text { effects in TPO- } \\
\text { Ab women living } \\
\text { in an area with } \\
\text { mild to moder- } \\
\text { ate ID. }\end{array}$ \\
\hline
\end{tabular}


Appendix 3 (Continued)

\begin{tabular}{|c|c|c|c|c|c|c|c|c|c|c|c|c|}
\hline $\begin{array}{l}\text { Reference, } \\
\text { details, first } \\
\text { author year, } \\
\text { country }\end{array}$ & $\begin{array}{l}\text { Study } \\
\text { design }\end{array}$ & $\begin{array}{l}\text { Population, } \\
\text { subject }\end{array}$ & $\begin{array}{l}\text { Outcome } \\
\text { measures }\end{array}$ & $\begin{array}{l}\text { Intervention/ } \\
\text { exposure }\end{array}$ & $\begin{array}{l}\text { Time between } \\
\text { baseline exposure } \\
\text { and outcome } \\
\text { assessment }\end{array}$ & $\begin{array}{l}\text { Dietary } \\
\text { assessment } \\
\text { method }\end{array}$ & $\begin{array}{c}\text { No. of } \\
\text { subjects } \\
\text { analyzed }\end{array}$ & 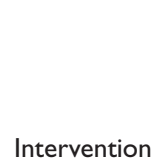 & $\begin{array}{l}\text { Follow-up } \\
\text { period, } \\
\text { drop-out } \\
\text { rate }\end{array}$ & Results & $\begin{array}{l}\text { Confounders } \\
\text { adjusted for }\end{array}$ & $\begin{array}{l}\text { Study quality and } \\
\text { relevance, } \\
\text { Comments } \\
\text { A-C }\end{array}$ \\
\hline & & $\begin{array}{l}\text { Randomised } \\
\text { and stratified } \\
\text { according to } \\
\text { TPO-Ab level to } \\
\text { three groups. }\end{array}$ & $\begin{array}{l}\text { was abnor- } \\
\text { mal and } \\
\text { clinical hy- } \\
\text { pothyroid- } \\
\text { ism if TSH } \\
\text { and thyroid } \\
\text { hormones } \\
\text { were } \\
\text { abnormal). }\end{array}$ & & & & & & & $\begin{array}{l}\text { given to } \\
\text { TPO-Ab } \\
\text { positive } \\
\text { women } \\
\text { during } \\
\text { pregnancy } \\
\text { only or } \\
\text { during } \\
\text { pregnancy } \\
\text { and the } \\
\text { post-partum } \\
\text { period. }\end{array}$ & & \\
\hline
\end{tabular}


Appendix 4. (studies presented in summary table 2). Prenatal iodine status and cognitive function in the offspring.

Reference,

Reference,

details, first author

year, country

Choudhury \&

Gorman 2003.

China (I5)

\begin{tabular}{|c|c|c|c|c|c|c|c|c|c|}
\hline $\begin{array}{l}\text { Study } \\
\text { design }\end{array}$ & $\begin{array}{l}\text { Population, } \\
\text { subject }\end{array}$ & $\begin{array}{l}\text { Outcome } \\
\text { measures }\end{array}$ & $\begin{array}{l}\text { Intervention/ } \\
\text { exposure }\end{array}$ & $\begin{array}{l}\text { Time between } \\
\text { baseline exposure } \\
\text { and outcome } \\
\text { assessment }\end{array}$ & $\begin{array}{c}\text { No. of subjects } \\
\text { analyzed }\end{array}$ & $\begin{array}{l}\text { Follow-up } \\
\text { period, drop-out } \\
\text { rate }\end{array}$ & Results & $\begin{array}{l}\text { Confounders } \\
\text { adjusted for }\end{array}$ & $\begin{array}{l}\text { Study quality } \\
\text { and relevance, } \\
\text { Comments A-C }\end{array}$ \\
\hline $\begin{array}{l}\text { Cohort } \\
\text { study }\end{array}$ & $\begin{array}{l}\text { Infants } \\
\text { ( } n=284 \text { ) from } \\
\text { a non-endemic } \\
\text { region of } \\
\text { Northern } \\
\text { China. No } \\
\text { information on } \\
\text { how they } \\
\text { were selected } \\
\text { to the study. } \\
\text { Stratification } \\
\text { of infants into } \\
\text { iodine defi- } \\
\text { ciency groups } \\
\text { (ID) by cord } \\
\text { blood TSH } \\
\text { concentration } \\
\text { (group I } \\
\text { (control) <5 } \\
\text { mU/L, group } 2: \\
\text { I0.0-19.9 } \mathrm{mU/} \\
\text { L, group } 3: \\
20.0-29.9 \mathrm{mU/} \\
\text { L, group } 4 \geq \\
30 \text { mU/L). } \\
\text { Gender } \\
\text { distribution in } \\
\text { groups } \\
\text { approximately } \\
\text { equal. }\end{array}$ & $\begin{array}{l}\text { Infant informa- } \\
\text { tion processing } \\
\text { (FTII) at } 7 \\
\text { months ( } n= \\
275 \text { ). Infant cog- } \\
\text { nitive and motor } \\
\text { development } \\
\text { (BSID-II) at I3 } \\
\text { months ( } n= \\
\text { I35). The BSID- } \\
\text { II was subdivided } \\
\text { into mental de- } \\
\text { velopment index } \\
\text { (MDI) and psy- } \\
\text { chomotor devel- } \\
\text { opment index } \\
\text { (PDI) }\end{array}$ & 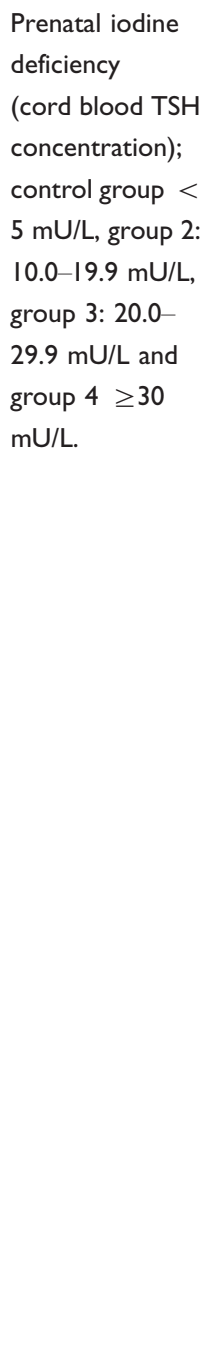 & 7 and 13 months & $\begin{array}{l}n=275 \text { at } 7 \text { months } \\
\text { and } n=135 \text { at } 13 \\
\text { months }\end{array}$ & $\begin{array}{l}\text { FTII at } 7 \text { months } \\
\text { available for } 96 \% \\
\text { of the original } \\
\text { group. BSID-II } \\
\text { at I } 3 \text { months } \\
\text { available for } 49 \% \\
\text { of the original } \\
\text { group. }\end{array}$ & $\begin{array}{l}\text { Infants in the } \\
\text { highest TSH cord } \\
\text { blood concentra- } \\
\text { tion groups } \\
\text { ( } 3 \text { and } 4) \text {, had } \\
\text { lower novelty } \\
\text { preference } \\
(57.7 \pm 5.6 \\
\text { and } 57.5 \pm 3.1 \text {, } \\
\text { respectively) } \\
\text { (suggesting } \\
\text { less efficient } \\
\text { information } \\
\text { processing) than } \\
\text { infants in the } \\
\text { non-elevated } \\
\text { and the mildly } \\
\text { elevated groups } \\
\text { ( } 1 \text { and } 2,59.6 \pm \\
3.0 \text { and } 58.9 \pm \\
4.3, \text { respectively, } \\
P<0.05) \text {. The } \\
\text { three elevated } \\
\text { TSH groups } \\
(2,3 \text { and } 4) \text { had } \\
\text { significantly lower } \\
\text { MDI scores than } \\
\text { the non-elevated } \\
\text { control group } \\
(98.2 \pm 8.3 \text {, } \\
98.7 \pm 9.3 \text { and } \\
93.5 \pm I 1.1 \text { vs. } \\
102.5 \pm 8.2\end{array}$ & $\begin{array}{l}\text { Maternal educa- } \\
\text { tion, place of resi- } \\
\text { dence (rural vs. } \\
\text { urban) and mater- } \\
\text { nal occupation. }\end{array}$ & $\begin{array}{l}\text { B No information } \\
\text { on iodine } \\
\text { nutrition } \\
\text { (neither urine } \\
\text { iodine nor iodine } \\
\text { intake). The } \\
\text { overall novelty } \\
\text { preference score } \\
\text { and MDI score } \\
\text { was well within } \\
\text { the expected } \\
\text { range in all } \\
\text { groups. }\end{array}$ \\
\hline
\end{tabular}




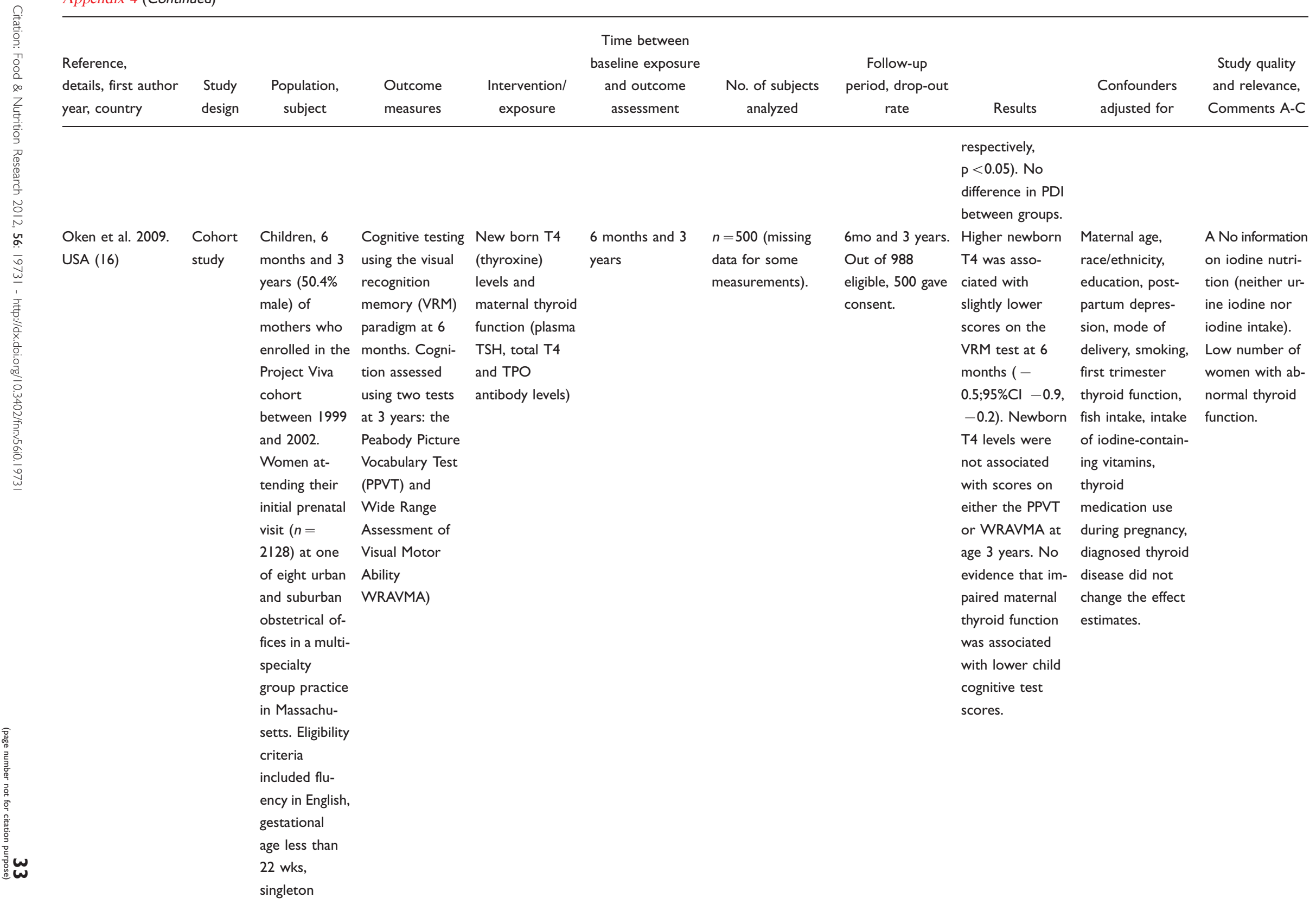


Appendix 4 (Continued)

\begin{tabular}{|c|c|c|c|c|c|c|c|c|c|c|}
\hline $\begin{array}{l}\text { Reference, } \\
\text { details, first author } \\
\text { year, country }\end{array}$ & $\begin{array}{l}\text { Study } \\
\text { design }\end{array}$ & $\begin{array}{l}\text { Population, } \\
\text { subject }\end{array}$ & $\begin{array}{l}\text { Outcome } \\
\text { measures }\end{array}$ & $\begin{array}{l}\text { Intervention/ } \\
\text { exposure }\end{array}$ & $\begin{array}{l}\text { Time between } \\
\text { baseline exposure } \\
\text { and outcome } \\
\text { assessment }\end{array}$ & $\begin{array}{c}\text { No. of subjects } \\
\text { analyzed }\end{array}$ & $\begin{array}{c}\text { Follow-up } \\
\text { period, drop-out } \\
\text { rate }\end{array}$ & Results & $\begin{array}{l}\text { Confounders } \\
\text { adjusted for }\end{array}$ & $\begin{array}{l}\text { Study quality } \\
\text { and relevance, } \\
\text { Comments A-C }\end{array}$ \\
\hline & & $\begin{array}{l}\text { pregnancy, } \\
\text { and plans to } \\
\text { remain in the } \\
\text { study area. Of } \\
2128 \text { women } \\
\text { in the Project } \\
\text { Viva who } \\
\text { delivered a live } \\
\text { infant, } 988 \text { had } \\
\text { info on first } \\
\text { trimester diet } \\
\text { and infant } \\
\text { cognitive test- } \\
\text { ing at } 6 \\
\text { months, and } \\
\text { were thus } \\
\text { eligible for } \\
\text { inclusion in } \\
\text { the present } \\
\text { study. } \\
\text { Maternal T4 } \\
\text { (mcg/dL) } 9.98 \\
\pm 1.95 \\
\text { (n=496). }\end{array}$ & & & & & & & & \\
\hline
\end{tabular}


Appendix 5. (studies presented in summary table 3). Iodine supplementation or improved iodine status in childhood and cognitive function.

\begin{tabular}{|c|c|c|c|c|c|c|c|c|c|c|c|c|}
\hline $\begin{array}{l}\text { Reference, } \\
\text { details, first } \\
\text { author year, } \\
\text { country }\end{array}$ & $\begin{array}{l}\text { Study } \\
\text { design }\end{array}$ & $\begin{array}{l}\text { Population, } \\
\text { subject }\end{array}$ & $\begin{array}{l}\text { Outcome } \\
\text { measures }\end{array}$ & $\begin{array}{l}\text { Intervention/ } \\
\text { exposure }\end{array}$ & $\begin{array}{l}\text { Time be- } \\
\text { tween base- } \\
\text { line exposure } \\
\text { and outcome } \\
\text { assessment }\end{array}$ & $\begin{array}{l}\text { Dietary } \\
\text { assessment } \\
\text { method }\end{array}$ & $\begin{array}{l}\text { No. of } \\
\text { subjects } \\
\text { analyzed }\end{array}$ & Intervention & $\begin{array}{l}\text { Follow-up period, } \\
\text { drop-out rate }\end{array}$ & Results & $\begin{array}{l}\text { Confounders } \\
\text { adjusted for }\end{array}$ & $\begin{array}{l}\text { Study quality and } \\
\text { relevance, } \\
\text { Comments A-C }\end{array}$ \\
\hline $\begin{array}{l}\text { Gordon } \\
\text { et al., } 2009 . \\
\text { New } \\
\text { Zeeland } \\
\text { (Dunedin) } \\
\text { (23) }\end{array}$ & $\begin{array}{l}\text { RCT, } \\
\text { double- } \\
\text { blind. }\end{array}$ & $\begin{array}{l}\text { Children, 10-13 } \\
\text { years, no } \\
\text { known } \\
\text { history of } \\
\text { thyroid } \\
\text { conditions, not } \\
\text { taking I supple- } \\
\text { ment. } 162 \\
\text { children } \\
\text { recruited from } \\
\text { schools, } 22 \\
\text { from } \\
\text { advertisement, } \\
\text { all together } \\
184.55 \% \text { boys. } \\
\text { Baseline UIC } 63 \\
\text { mcg/L, } \\
\text { Thyroglobulin } \\
16.4 \text { mcg/L, } \\
\text { Total Thyroxine } \\
104 \pm 28.1 \\
\text { nmol/L. }\end{array}$ & $\begin{array}{l}\text { Cognitive } \\
\text { performance. } \\
\text { Wechsler } \\
\text { Intelligence } \\
\text { Scale for } \\
\text { Children. } \\
\text { Subtests: } \\
\text { Picture } \\
\text { concepts, } \\
\text { matrix } \\
\text { reasoning, } \\
\text { symbol search, } \\
\text { letter-number } \\
\text { sequencing. }\end{array}$ & $\begin{array}{l}\text { I } 50 \text { mcg I } \\
\text { tablet vs. } \\
\text { Placebo. }\end{array}$ & $28 \mathrm{wk}$ & $\begin{array}{l}\text { FFQ, foods } \\
\text { considered as } \\
\text { main sources } \\
\text { of I. Caregiver } \\
\text { completed a } \\
\text { FFQ about in- } \\
\text { take of dairy } \\
\text { products, } \\
\text { milk, red } \\
\text { meat, poultry, } \\
\text { fish, shellfish, } \\
\text { pulses and le- } \\
\text { gumes, fruit, } \\
\text { eggs, and io- } \\
\text { dized salt. }\end{array}$ & $\begin{array}{l}n=166.1 \\
\text { group } \\
n=84 \text { and } \\
\text { placebo } \\
n=82 .\end{array}$ & $\begin{array}{l}\text { Children were } \\
\text { provided with 4-wk } \\
\text { supplements in } \\
\text { 28-day compliance } \\
\text { packaging blister } \\
\text { packs and an infor- } \\
\text { mation sheet how } \\
\text { to take their sup- } \\
\text { plements. Every } 4 \\
\text { wks a new pack of } \\
\text { supplements was } \\
\text { posted. Return en- } \\
\text { velope included to } \\
\text { collect previous } \\
\text { months supple- } \\
\text { ments. If a pack } \\
\text { was not returned, } \\
\text { the compliance was } \\
\text { assumed to be zero } \\
\text { for that month. } \\
\text { Movie vouchers, } \\
\text { small stationary } \\
\text { items, or shopping } \\
\text { vouchers were sent } \\
\text { out during the } \\
\text { study to aid with } \\
\text { compliance. }\end{array}$ & $\begin{array}{l}\text { II drop-out in I } \\
\text { group, } 7 \text { in } \\
\text { placebo. Total } \\
\text { drop-out I I\%. }\end{array}$ & $\begin{array}{l}\text { After } 28 \text { wk: I group } \\
\text { UIC I } 45 \mathrm{mcg} / \mathrm{L} \text {, } \\
\text { Thyroglobulin } 8.5 \\
\text { mcg/L. Placebo group } \\
\text { UIC } 81 \mathrm{mcg} / \mathrm{L} \text {, Thyr- } \\
\text { oglobulin II.6 mcg/L. } \\
2 \text { of } 4 \text { cognitive } \\
\text { subtest significantly } \\
\text { improved in the I } \\
\text { group. Perceptual } \\
\text { reasoning in mildly } \\
\text { ID children were } \\
\text { improved in I group. } \\
\text { Picture concept } \\
\text { associated with } 0.8 \text { I } \\
\text { age-standardized } \\
\text { point improvement } \\
\text { in iodine relative to } \\
\text { placebo }(p=0.023) \text {, } \\
\text { and } 0.63 \text { points in } \\
\text { matrix reasoning } \\
(p=0.040) \text {. }\end{array}$ & $\begin{array}{l}\text { Sex, method of } \\
\text { recruitment, } \\
\text { cohort, ethni- } \\
\text { city and house- } \\
\text { hold income. }\end{array}$ & $\begin{array}{l}\text { B Results are impor- } \\
\text { tant and relevant in a } \\
\text { Nordic perspective } \\
\text { since the study is } \\
\text { among children in } \\
\text { mildly iodine-defi- } \\
\text { cient area. Suggest } \\
\text { that mild ID could } \\
\text { prevent children } \\
\text { from attaining their } \\
\text { full intellectual } \\
\text { potential. }\end{array}$ \\
\hline $\begin{array}{l}\text { Zimmermann } \\
\text { et al., } 2006 . \\
\text { Albania (24) }\end{array}$ & $\begin{array}{l}\text { RCT, } \\
\text { double- } \\
\text { blind }\end{array}$ & $\begin{array}{l}\text { All children - } \\
10-12 \text { years at } \\
7 \text { primary } \\
\text { schools in } \\
\text { villages in the } \\
\text { Korce/Pogradec } \\
\text { district of } \\
\text { southeastern } \\
\text { Albania were } \\
\text { invited, } n=310 \\
\text { ( } 166 \text { boys and } \\
144 \text { girls). }\end{array}$ & $\begin{array}{l}\text { Morning spot } \\
\text { urine, TSH, total } \\
\text { thyroxine (TT4) } \\
\text { and thyroid } \\
\text { gland volume. } 7 \\
\text { cognitive and } \\
\text { motor skills } \\
\text { tests (measures } \\
\text { of information } \\
\text { processing, } \\
\text { working } \\
\text { memory, visual } \\
\text { problem solving, } \\
\text { visual search and } \\
\text { fine motor } \\
\text { skills). }\end{array}$ & $\begin{array}{l}400 \mathrm{mg} \text { iodine } \\
\text { as oral } \\
\text { iodized oil vs. } \\
\text { placebo. }\end{array}$ & 24 wk & $\begin{array}{l}\text { None, only } \\
\text { UIC. }\end{array}$ & $\begin{array}{l}n=159 \text { in I } \\
\text { group and } \\
n=151 \text { in } \\
\text { placebo } \\
\text { group. }\end{array}$ & $\begin{array}{l}\text { After baseline test- } \\
\text { ing the children } \\
\text { were randomly } \\
\text { assigned to receive } \\
400 \mathrm{mcg} \text { oral I as } \\
\text { iodized poppy seed } \\
\text { oil (Lipiodol) or a } \\
\text { sunflower oil } \\
\text { (placebo). The } \\
\text { capsules were } \\
\text { swallowed with } \\
\text { water under direct } \\
\text { supervision. }\end{array}$ & $\begin{array}{l}6 \text { children moved } \\
\text { and did not } \\
\text { complete the cog- } \\
\text { nitive retesting } \\
(4 \text { in I group, } 2 \text { in } \\
\text { placebo group) } \\
\text { (4\%). Thyroid } \\
\text { function tests was } \\
\text { not measured at } \\
\text { follow up in } 12 \% \\
\text { of the children } \\
\text { because they } \\
\text { refused blood } \\
\text { sampling. }\end{array}$ & $\begin{array}{l}\text { I group: UIC in- } \\
\text { creased from } 42(0- \\
\text { I86) to I72 (I8-724) } \\
\mu \mathrm{g} / \mathrm{L} \text {, Thyroid volume } \\
\text { reduced from } 5.9 \\
(2.6-12.5) \text { to } 5.0 \\
(2.4-9.7) \mathrm{mL} \text {, TSH } \\
\text { unchanged } 0.8(0.3- \\
2.5) \text { and } 0.7(2.4- \\
2.6), \mathrm{TT} 4 \text { increased } \\
\text { from } 76 \pm \text { I7 to } \\
106 \pm 18 \mathrm{nmol} / \mathrm{L} \text {. Pla- } \\
\text { cebo group: UIC un- } \\
\text { changed } 44(0-215) \\
\text { and } 49(3-22 \mathrm{I}) \text {, } \\
\text { thyroid volume un- } \\
\text { changed } 6.2(2.1- \\
\text { 16.8) and } 6.3\end{array}$ & $\begin{array}{l}\text { Baseline differ- } \\
\text { ence between } \\
\text { groups, sex, and } \\
\text { school. }\end{array}$ & $\begin{array}{l}\text { B Study from an } \\
\text { iodine-deficient area } \\
\text { in Albania. Might not } \\
\text { be relevant for the } \\
\text { Nordic countries. }\end{array}$ \\
\hline
\end{tabular}


Appendix 5 (Continued)

\begin{tabular}{|c|c|c|c|c|c|c|c|c|c|c|c|c|}
\hline $\begin{array}{l}\text { Reference, } \\
\text { details, first } \\
\text { author year, } \\
\text { country }\end{array}$ & $\begin{array}{l}\text { Study } \\
\text { design }\end{array}$ & $\begin{array}{l}\text { Population, } \\
\text { subject }\end{array}$ & $\begin{array}{l}\text { Outcome } \\
\text { measures }\end{array}$ & $\begin{array}{l}\text { Intervention/ } \\
\text { exposure }\end{array}$ & $\begin{array}{l}\text { Time be- } \\
\text { tween base- } \\
\text { line exposure } \\
\text { and outcome } \\
\text { assessment }\end{array}$ & $\begin{array}{l}\text { Dietary } \\
\text { assessment } \\
\text { method }\end{array}$ & $\begin{array}{l}\text { No. of } \\
\text { subjects } \\
\text { analyzed }\end{array}$ & Intervention & $\begin{array}{l}\text { Follow-up period, } \\
\text { drop-out rate }\end{array}$ & Results & $\begin{array}{l}\text { Confounders } \\
\text { adjusted for }\end{array}$ & $\begin{array}{l}\text { Study quality and } \\
\text { relevance, } \\
\text { Comments A-C }\end{array}$ \\
\hline $\begin{array}{l}\text { van den Briel } \\
\text { et al., } 2000 . \\
\text { West Africa } \\
(25)\end{array}$ & $\begin{array}{l}\text { RCT, } \\
\text { double } \\
\text { blind. } \\
\text { Data } \\
\text { treated as } \\
\text { cohort } \\
\text { study. }\end{array}$ & $\begin{array}{l}\text { Children 6-12 } \\
\text { years from four } \\
\text { primary schools } \\
n=211 \text { (ap- } \\
\text { prox. } 85 \% \\
\text { boys). }\end{array}$ & $\begin{array}{l}\text { Height, weight, } \\
\text { blood (TSH, } \\
\text { serum ferritin, } \\
\text { Tg, free T4), } \\
\text { urine. Mental } \\
\text { test battery: } \\
\text { closure, } \\
\text { concentration, } \\
\text { exclusion, } \\
\text { fluency, mazes, } \\
\text { hand } \\
\text { movements, } \\
\text { colored } \\
\text { progressive } \\
\text { matrices. Two } \\
\text { psychomotor } \\
\text { tests - pegboard } \\
\text { and ball } \\
\text { throwing. }\end{array}$ & $\begin{array}{l}\text { lodine } \\
\text { supplement (I } \\
\mathrm{mL} \text { iodized oil } \\
540 \mathrm{~g} \mathrm{I} / \mathrm{L}) \text { or } \\
\text { placebo. }\end{array}$ & $\begin{array}{l}\text { Baseline mea- } \\
\text { surements in } \\
\text { Oct and Nov } \\
1995 . \\
\text { repeated in } \\
\text { Oct and Nov } \\
1996 .\end{array}$ & $\begin{array}{l}\text { None, only } \\
\text { UIC. }\end{array}$ & $\begin{array}{l}\text { Improved } \\
\text { group } \\
(n=128), \\
\text { unchanged } \\
\text { group } \\
(n=68) .\end{array}$ & $\begin{array}{l}\text { As the population } \\
\text { began to have ac- } \\
\text { cess to iodized salt } \\
\text { during the inter- } \\
\text { vention period, the } \\
\text { study population } \\
\text { was split post hoc } \\
\text { on the basis of UIC } \\
\text { into group with } \\
\text { improved iodine } \\
\text { status and a group } \\
\text { with unchanged io- } \\
\text { dine status (i.e. } \\
\text { status changed } \\
\text { from severe iodine } \\
\text { deficiency to mod- } \\
\text { erate, from severe } \\
\text { to normal-mild, or } \\
\text { from moderate to } \\
\text { normal-mild). }\end{array}$ & $\begin{array}{l}13 \text { children left } \\
\text { school or moved } \\
\text { and } 2 \text { children } \\
\text { could not be lo- } \\
\text { cated during urine } \\
\text { collection. Drop- } \\
\text { out } 7 \% \text {. }\end{array}$ & $\begin{array}{l}\text { (2.6-I6.0) mL, TSH } \\
\text { unchanged } 0.9(0.4- \\
2.6) 0.8(0.2-7.7) \text {, } \\
\text { TT4 unchanged } 75 \\
\pm 17 \text { and } 81 \pm 19 \\
\text { nmol/L. I group sig- } \\
\text { nifies improved per- } \\
\text { formance on } 4 \text { of } 7 \\
\text { tests (mean adjusted } \\
\text { treatment effect } \\
(95 \% \text { CI)): Rapid } \\
\text { target marking } 2.8 \\
(1.6-4.0) \text {, symbol } \\
\text { search } 2.8 \text { (1.9-3.6), } \\
\text { rapid object naming } \\
4.5(2.3-6.6) \text {, and } \\
\text { Raven's Coloured } \\
\text { Progressive Matrices } \\
4.7 \text { (3.8-5.8). } \\
\text { Children with } \\
\text { increased UIC from } \\
\text { baseline to endpoint } \\
\text { (improved iodine } \\
\text { status) had signifi- } \\
\text { cantly greater in- } \\
\text { crease in } \\
\text { performance on } \\
\text { the combination of } \\
\text { mental tests than did } \\
\text { the group with no } \\
\text { change in UIC } \\
(0.12 \pm 0.06, P= \\
01044) \text {. }\end{array}$ & $\begin{array}{l}\text { Both groups } \\
\text { consisted of } \\
\text { supplemented } \\
\text { and non- } \\
\text { supplemented } \\
\text { children, pro- } \\
\text { portions not } \\
\text { different. Also } \\
\text { comparable in } \\
\text { HB concentra- } \\
\text { tion, anthropo- } \\
\text { metric and } \\
\text { socioeconomic } \\
\text { indexes and } \\
\text { initial scores } \\
\text { on the mental } \\
\text { tests. }\end{array}$ & $\begin{array}{l}\text { B Study includes } \\
\text { schoolchildren in } \\
\text { Benin and reflects } \\
\text { not Nordic coun- } \\
\text { tries. The results } \\
\text { suggest a "catch up" } \\
\text { effects in terms of } \\
\text { mental performance } \\
\text { after iodine } \\
\text { supplementation. }\end{array}$ \\
\hline
\end{tabular}


Appendix 6. (studies presented in summary table 4). Iodine status and health outcomes in adults and elderly.

\begin{tabular}{|c|c|c|c|c|c|c|c|c|c|c|}
\hline $\begin{array}{l}\text { Reference, de- } \\
\text { tails, first author } \\
\text { year, country }\end{array}$ & Study design & $\begin{array}{l}\text { Population, } \\
\text { subject }\end{array}$ & $\begin{array}{l}\text { Outcome } \\
\text { measures }\end{array}$ & $\begin{array}{l}\text { Intervention/ } \\
\text { exposure }\end{array}$ & $\begin{array}{c}\text { Time between } \\
\text { baseline exposure and } \\
\text { outcome } \\
\text { assessment }\end{array}$ & $\begin{array}{l}\text { No. of subjects } \\
\text { analyzed }\end{array}$ & $\begin{array}{l}\text { Follow-up } \\
\text { period, drop- } \\
\text { out rate }\end{array}$ & Results & $\begin{array}{l}\text { Confounders } \\
\text { adjusted for }\end{array}$ & $\begin{array}{l}\text { Study quality and } \\
\text { relevance, } \\
\text { Comments A-C }\end{array}$ \\
\hline $\begin{array}{l}\text { Ayturk et al., } \\
\text { 2009. Turkey } \\
\text { (32) }\end{array}$ & Case-control study. & $\begin{array}{l}\text { New patients ( } 18-74 \\
\text { years) with metabolic } \\
\text { syndrome }(n=278) \\
\text { living in a mild-to } \\
\text { moderate iodine defi- } \\
\text { ciency area, who } \\
\text { attended for regular } \\
\text { follow-up. } 26 \mid \text { euthyr- } \\
\text { oid control subjects } \\
\text { without known thyroid } \\
\text { disease recruited from } \\
\text { patients admitting to } \\
\text { family outpatient clinic. } \\
\text { Matched according to } \\
\text { age, gender, and } \\
\text { smoking. }\end{array}$ & $\begin{array}{l}\text { TSH, thyroid } \\
\text { volume and no- } \\
\text { dule prevalence. }\end{array}$ & & & $\begin{array}{l}n=539 ; n=278 \\
\text { in the Mets } \\
\text { group (33.1\% } \\
\text { male) and } n= \\
261 \text { in the } \\
\text { control group } \\
(30.7 \% \text { male) }\end{array}$ & & $\begin{array}{l}\text { TSH was } \\
\text { significantly } \\
\text { correlated with the } \\
\text { presence } \\
\text { of MetS. In a multiple } \\
\text { linear regression } \\
\text { analysis, indepen- } \\
\text { dent predictors of } \\
\text { thyroid volume (mL) } \\
\text { were (B, } 95 \% \mathrm{Cl}) \text {; } \\
\text { waist circumference } \\
(\mathrm{cm}) 0.335(0.089- \\
0.161) \text {, triglycerides } \\
(\mathrm{mg} / \mathrm{dL}) 0.136 \\
(0.003-0.016) \text {, and } \\
\text { insulin resistance } \\
0.143(0.512-2.731) .\end{array}$ & $\begin{array}{l}\text { BMI, smoking, fat- } \\
\text { mass }\end{array}$ & $\begin{array}{l}\text { B No information on } \\
\text { iodine } \\
\text { nutrition (neither } \\
\text { urine iodine nor } \\
\text { iodine intake). Pa- } \\
\text { tients with MetS } \\
\text { have } \\
\text { signifies increased } \\
\text { thyroid volume and } \\
\text { nodule prevalence. } \\
\text { Insulin } \\
\text { resistance is sug- } \\
\text { gested as an inde- } \\
\text { pendent risk factor } \\
\text { for nodule formation } \\
\text { in an iodine- } \\
\text { deficient } \\
\text { environment. }\end{array}$ \\
\hline $\begin{array}{l}\text { Hoption Cann } \\
\text { et al., 2007. USA } \\
\text { (33) }\end{array}$ & Cohort study. & $\begin{array}{l}\text { NHEFS, } 25-74 \text { years, } \\
n=58 I I \text { males. Ex- } \\
\text { cluded due to lack of } \\
\text { urinary iodine at base- } \\
\text { line }(n=1577) \text {, leaving } \\
4234 \text { men for analysis. } \\
\text { Mean age at examina- } \\
\text { tion } 52.7 \text { years, } 16.5 \% \\
\text { non-white. } \\
\text { Tertiles of lodine/ } \\
\text { Creatinine } \\
\text { categories ( }<201 \\
n=\mid 452,201-345 \\
n=\mid 554,>345 n= \\
\text { I228, } \\
\text { referred to as low, } \\
\text { moderate and high } \\
\text { levels). }\end{array}$ & $\begin{array}{l}\text { Prostate cancer } \\
\text { incidence. }\end{array}$ & $\begin{array}{l}\text { lodine status } \\
\text { (UIC and } \\
\text { UI/Cr ratio). } \\
\text { Spot samples. }\end{array}$ & $\begin{array}{l}\text { Baseline in } 197 \mid \text { and } \\
\text { 1975, Follow up in 1982- } \\
\text { 1984, 1986, } \\
\text { 1987 and 1992). }\end{array}$ & $\begin{array}{l}n=4234 \\
\text { subjects, } \\
n=197 \\
\text { cases. }\end{array}$ & $\begin{array}{l}7-21 \text { years } \\
\text { Drop-out } \\
10 \% .\end{array}$ & 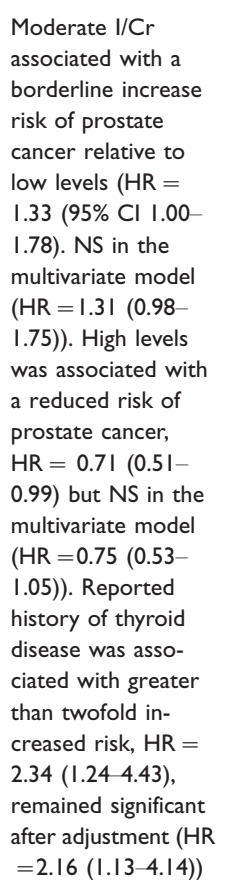 & $\begin{array}{l}\text { Age, race, marital } \\
\text { status, family in- } \\
\text { come, alcohol } \\
\text { consumption at } \\
\text { baseline, region }\end{array}$ & $\begin{array}{l}\text { environment. } \\
\text { B The role of iodine } \\
\text { remains speculative, } \\
\text { a role of thyroid } \\
\text { disease and/or fac- } \\
\text { tors contributing to } \\
\text { thyroid disease as a } \\
\text { risk factor for pros- } \\
\text { tate carcinogenesis } \\
\text { warrants additional } \\
\text { investigation. }\end{array}$ \\
\hline
\end{tabular}


Appendix 7. (studies presented in summary table 5). Excessive intake of iodine.

\begin{tabular}{|c|c|c|c|c|c|c|c|c|c|c|c|c|}
\hline $\begin{array}{l}\text { Reference, details, } \\
\text { first author year, } \\
\text { country }\end{array}$ & $\begin{array}{l}\text { Study } \\
\text { design }\end{array}$ & $\begin{array}{l}\text { Population, } \\
\text { subject }\end{array}$ & $\begin{array}{l}\text { Outcome } \\
\text { measures }\end{array}$ & $\begin{array}{l}\text { Intervention/ } \\
\text { exposure }\end{array}$ & $\begin{array}{l}\text { Time between } \\
\text { baseline } \\
\text { exposure and } \\
\text { outcome } \\
\text { assessment }\end{array}$ & $\begin{array}{l}\text { Dietary } \\
\text { assessment } \\
\text { method }\end{array}$ & $\begin{array}{l}\text { No. of subjects } \\
\text { analyzed }\end{array}$ & 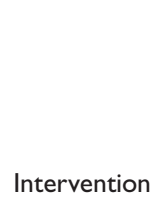 & $\begin{array}{l}\text { Follow-up } \\
\text { period, d } \\
\text { rop-out } \\
\text { rate }\end{array}$ & Results & $\begin{array}{l}\text { Confounders } \\
\text { adjusted for }\end{array}$ & $\begin{array}{l}\text { Study quality } \\
\text { and } \\
\text { relevance, } \\
\text { Comments } \\
\text { A-C }\end{array}$ \\
\hline $\begin{array}{l}\text { Zimmermannet al., } \\
\text { 2005. Multiethnic } \\
\text { (North and South } \\
\text { America, Central } \\
\text { Europe, Eastern } \\
\text { Mediterranean, } \\
\text { Africa and the } \\
\text { Western } \\
\text { Pacific) (34) }\end{array}$ & $\begin{array}{l}\text { Cross- } \\
\text { sectional. }\end{array}$ & $\begin{array}{l}\text { 6-12 year children } \\
\text { primary schools } \\
\text { whose pupils were } \\
\text { of middle-to-low } \\
\text { socioeconomic } \\
\text { status. }\end{array}$ & $\begin{array}{l}\text { Thyroid } \\
\text { volume } \\
\text { (by ultrasound } \\
\text { measurement). }\end{array}$ & $\begin{array}{l}\text { lodine intake } \\
\text { assessed } \\
\text { by UIC in } \\
\text { spot urine } \\
\text { samples. }\end{array}$ & & $\begin{array}{l}\text { None, only } \\
\text { UI. }\end{array}$ & $\begin{array}{l}n=3319 . \\
\text { ( } n=534 \text { from } \\
\text { Switzerland, } \\
n=526 \text { from } \\
\text { Bahrain, } \\
n=59 \mid \text { from } \\
\text { South Africa, } \\
n=524 \text { from } \\
\text { Peru, } n=562 \\
\text { from Chelsea } \\
\text { MA, } n=302 \\
\text { from central } \\
\text { Japan, } n=280 \\
\text { from coastal } \\
\text { Japan). }\end{array}$ & & & $\begin{array}{l}31 \% \text { of } \\
\text { children had } \\
\text { UIC }>300 \\
\mathrm{mcg} / \mathrm{L} \text { and } \\
\mathrm{II} \%>500 \\
\mathrm{mcg} / \mathrm{L} \text {. UIC } \\
\text { of } 300-500 \\
\mathrm{mcg} / \mathrm{L} \text { not } \\
\text { associated } \\
\text { with } \\
\text { increased } \\
\text { Tvol. Tvol } \\
\text { started to } \\
\text { increase at a } \\
\text { UIC } \approx 500 \\
\text { mcg } / \mathrm{L} .\end{array}$ & $\begin{array}{l}\text { Age, sex and } \\
\text { body surface } \\
\text { area (BSA). }\end{array}$ & $\begin{array}{l}\text { B The } \\
\text { authors don't } \\
\text { rule out } \\
\text { adverse ef- } \\
\text { fects of UIC } \\
\text { in the range } \\
\text { of } 300-500 \\
m c g / \text { day not } \\
\text { detected in } \\
\text { this study. }\end{array}$ \\
\hline
\end{tabular}

